\title{
Limnological changes in Lake Victoria since the mid-20 century
}

\author{
Loris Deirmendjian $^{1}$ (D) | Jean-Pierre Descy ${ }^{1}$ (D) | Cedric Morana, ${ }^{1,2}$ (i) | William Okello ${ }^{3}$ \\ Maya P. Stoyneva-Gärtner ${ }^{4}$ (D) | Steven Bouillon ${ }^{2}$ (D) | Alberto V. Borges ${ }^{1}$ (D)
}

${ }^{1}$ Chemical Oceanography Unit, University of Liège, Liège, Belgium

${ }^{2}$ Department of Earth and Environmental Sciences, KU Leuven, Leuven, Belgium

${ }^{3}$ National Fisheries Resource Research Institute, Jinja, Uganda

${ }^{4}$ University of Sofia St Kliment Ohridski, Sofia, Bulgaria

\section{Correspondence}

Loris Deirmendjian, Chemical Oceanography Unit, University of Liège, Liège, Belgium.

Email: lorisdeir@gmail.com

Present address

Loris Deirmendjian, Geosciences

Environnement Toulouse UMR 5563 \& UR 234 IRD, Université Paul-Sabatier, Toulouse, France

Funding information

T.0156.18

\section{Abstract}

1. Lake Victoria experienced a strong degradation of water quality between the 1960 s and the 1990s and, as a consequence of eutrophication, the dominant phytoplankton group changed from diatoms to $\mathrm{N}_{2}$-fixing cyanobacteria and there was a 2- to 10-fold increase in chlorophyll-a. The goal of this study is to determine whether the 2018-2019 physical (light, stratification) and ecological (nutrient, chlorophyll-a, phytoplankton composition) conditions in Lake Victoria changed from the 1990s.

2. Samples were collected in 2018-2019 in nearshore and offshore waters (Uganda), during three contrasting seasons: heavy rains (March), low rains (October), and dry (June), which corresponded to distinct water column mixing regimes, respectively, late-stratified, early-stratified, and mixed regimes. At each station (48 nearshore and 25 offshore), we measured vertical profiles of temperature, oxygen, phytoplankton biomass and composition, inorganic nutrients, and particulate organic carbon, particulate nitrogen (N), and phosphorus (P).

3. Chlorophyll-a concentrations in 2018-2019 were $10.3 \pm 7.1$ and $2.8 \pm 1.1 \mu \mathrm{g} / \mathrm{L}$ in the nearshore and offshore surface waters, respectively, close to those measured in the 1960s before eutrophication, but distinctly lower than those measured in the 1990s ( $71 \pm 100$ and $14 \pm 6 \mu \mathrm{g} / \mathrm{L}$ ). The phytoplankton of Lake Victoria in 2018-2019 still appears dominated by diatoms and cyanobacteria. However, we observed more non-heterocystous filamentous and coccal/colonial cyanobacteria taxa that are better adapted to mixing conditions than gas-vacuolated heterocystous taxa, which were dominant in the 1990s. Particulate $\mathrm{N}$ was significantly lower in 2018-2019 than in the 1990s, indicative of less efficient $N$ fixation. The dissolved silica concentrations in 2018-2019 were significantly higher with the concomitant reappearance of Aulacoseira spp., which was not observed in the 1990s, presumably due to low dissolved silica concentrations.

4. As data from long-term monitoring are absent, the reasons for the lower chlorophyll-a concentrations in 2018-2019 compared to the 1990s are unclear. However, climatic controls (El Niño/La Niña conditions) may be an important factor influencing the historical trend in chlorophyll-a. Higher wind in 2018-2019 promoted vertical mixing, resulting in a deeper thermocline and surface mixed 
layers, which eventually lowered phytoplankton production in comparison to the 1990s. In contrast, the thermocline and surface mixed layers in the 1990s were shallower, enabling phytoplankton to stay suspended in the upper well illuminated water, allowing greater productivity. The lake in 2018-2019 is still P saturated, suggesting that another episode of high chlorophyll- $a$ concentrations could develop if less windy conditions occur in future, or if continued warming of surface waters eventually overcomes the mixing from present windy conditions.

5. This study gives insights about the present ecological functioning of Lake Victoria and emphasises the impacts of variations in climate on lake physics that changes the light environment for phytoplankton. A possible less windy period in the future resulting from a new El Niño phase or from climate change, will probably lead to another episode of eutrophication in Lake Victoria. As in 2018-2019 the lake was still saturated by nutrients, there is need to reduce the nutrient concentrations (especially $\mathrm{P}$ ) to prevent future destructive eutrophic periods caused by reduced mixing.

\section{KEYWORDS}

chlorophyll-a, ecology, Lake Victoria, plankton primary production

\section{1 | INTRODUCTION}

Lake Victoria, the source of the White Nile, and the world's most extensive $\left(68,800 \mathrm{~km}^{2}\right)$ tropical lake, has been the subject of several ecological studies because it is considered one of the critically important water and fisheries resource in East Africa, providing life support requirements to more than 47 million inhabitants from three bordering countries (Uganda, Tanzania, and Kenya) (UNEP, 2008). Information on the main environmental features of Lake Victoria was first given in the pioneering work of Worthington (1930), and quantitative studies on phytoplankton began with the works of Fish $(1955,1956,1957)$. Several investigations conducted from the 1960 s, dealing with the seasonality of phytoplankton production and abundance and their relationship to thermal, oxygen and nutrient regimes, provide an essential historical reference for the limnological conditions (Talling, 1957a, 1957b, 1965, 1966; Talling \& Talling, 1965). A comparison of data from the 1960s and the 1990s in offshore waters have shown the deterioration of water quality and eutrophication of Lake Victoria (Hecky, 1993; Hecky et al., 1994, 2010; Mugidde, 1992, 1993). Among the consequences of eutrophication, which co-occurred with the development of the introduced Nile perch (Lates niloticus) population, dissolved silica (DSi) decreased from 80 to $10 \mu \mathrm{mol} / \mathrm{L}$, and there was a 5-fold decrease in transparency and a 2- to 10fold increase in chlorophyll- $a$. In addition, the surface mixed layer depth decreased from $40-50 \mathrm{~m}$ to $30-40 \mathrm{~m}$, which might also have contributed to the observed changes of phytoplankton biomass and composition between the 1960s and 1990s. In the 1990s, higher photosynthesis and oxygen saturation levels occurred in surface waters offshore, where the biomass was 3-5 times greater than that observed in the 1960 s, while anoxic conditions occurred in deep waters (Hecky, 1993; Hecky et al., 1994). In the offshore waters, Mugidde (1993) reported a doubling of the phytoplankton productivity in the 1990 s compared to measurements three decades before. In the 1990s, the dominant phytoplankton group changed from diatoms (mainly Aulacoseira, formerly Melosira) to $\mathrm{N}_{2}$-fixing cyanobacteria (Kling et al., 2001) The strong decline of Aulacoseira in superficial sediment deposits indicates that the lake in the 1990s was much different than it had been during the past 10,000 years (Hecky, 1993).

The causes for the limnological transition of Lake Victoria observed in the 1990s are still debated (Hecky, 1993; Hecky et al. 2010). The hypotheses were: (1) nutrient enrichment resulting from land clearing, and growth of human and cattle populations; (2) trophic alterations caused by a trophic cascade of predator-prey interactions triggered by the introduction of Nile perch that eliminated endemic herbivores and released grazing control of phytoplankton, thereby increasing biomass; and (3) climate variations that reduced lake mixing, increased temperature, and caused a suite of chemical and biological consequences. In the absence of adequate historical monitoring data to link observed ecological change to possible causative factors, answers were partly given by palaeolimnological studies in offshore sediments (Hecky et al. 2010; Verschuren et al., 2002). Hecky et al. (2010) showed that the limnological transition of Lake Victoria started as early as the 1930s to eventually achieve by the mid-to-late $1980 \mathrm{~s}$ the levels of algal biomass and primary productivity observed in the 1990s. Verschuren et al. (2002) showed that timing and progress of the inferred productivity increase matched human population growth and agricultural activity in the Lake Victoria basin. Accordingly, the combined palaeolimnological evidence indicates that historical changes in phytoplankton productivity and 
composition of Lake Victoria were caused mainly by bottom-up effects of excess nutrient loading, and less by food-web alterations after the 1980s upsurge of Nile perch. Stager et al. (2009), based on diatom records in cores sampled in 2000, showed a change in the planktonic diatom assemblage, with a shift from Aulacoseira spp. to needle-shaped Nitzschia, indicative of a change of the silica-phosphorus supply ratio, which supported the bottom-up controls of eutrophication.

Verschuren et al. (2002) highlighted that estimates projecting a doubling of the regional human population to 53 million by 2020, and further degradation of the Lake Victoria ecosystem would be countered only if land management strategies that severely restrict nutrient input to the lake and its tributaries were implemented on a multinational, basin-wide scale. Within this context, the main goal of this study is to establish for the late 2010s the limnological conditions of Lake Victoria in the nearshore and offshore waters, and to compare those results with historical observations.

\section{2 | METHODS}

\section{1 | Study site}

Lake Victoria, source of the White Nile, is located in the upper Nile basin in East Africa within latitudes $3.05^{\circ} \mathrm{S}-0.55^{\circ} \mathrm{N}$ and longitudes $31.5^{\circ}-34.88^{\circ} \mathrm{E}$ (Figure 1). The shorelines of Lake Victoria are shared among three riparian East African countries: Tanzania (49\%), Uganda (45\%), and Kenya (6\%; Figure 1). The present lake surface area is large $\left(68,800 \mathrm{~km}^{2}\right)$ but the basin is relatively shallow with a mean depth of $40 \mathrm{~m}$ and a maximum depth of $80 \mathrm{~m}$ (Figure 1; Bootsma et al., 2003; Johnson et al., 2009). Lake Victoria surface is at an average elevation of approximately 1,135 m above sea level (Bootsma et al., 2003). The complex shoreline length is approximately $3,440 \mathrm{~km}$ and it is composed of several gulfs and bays (Figure 1; Akurut et al., 2017; Balirwa, 1995). Wetlands are sporadically present along the shoreline of Lake Victoria. In addition, several islands fringe the shore with combined surface area of approximately $1,500 \mathrm{~km}^{2}$ (Figure 1;

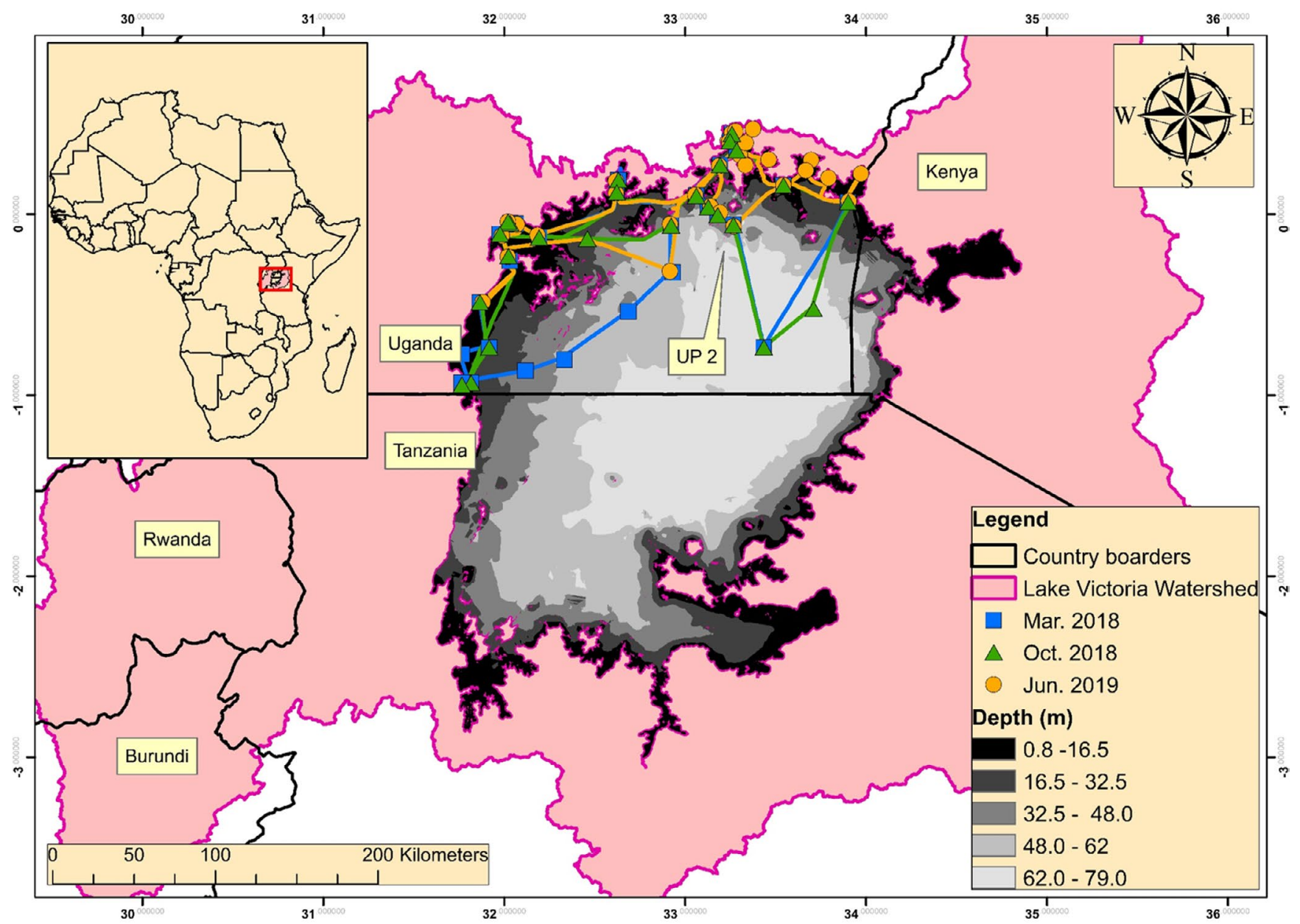

FIGURE 1 Map of Lake Victoria showing the catchment, the lake water depth, the sampling stations and the boat cruise-tracks during the three different field campaigns. The first campaign was conducted during the long rainy period corresponding to strongly stratified water column conditions (March 2018), the second one during the short rainy period corresponding to partly stratified water column conditions (October 2018) and the third one during the dry season corresponding to mixed water column conditions (June 2019). UP2 is an open water station corresponding to Talling's historical station (Bugaia) from which vertical physico-chemical profiles are presented in Figures 2 and 5 


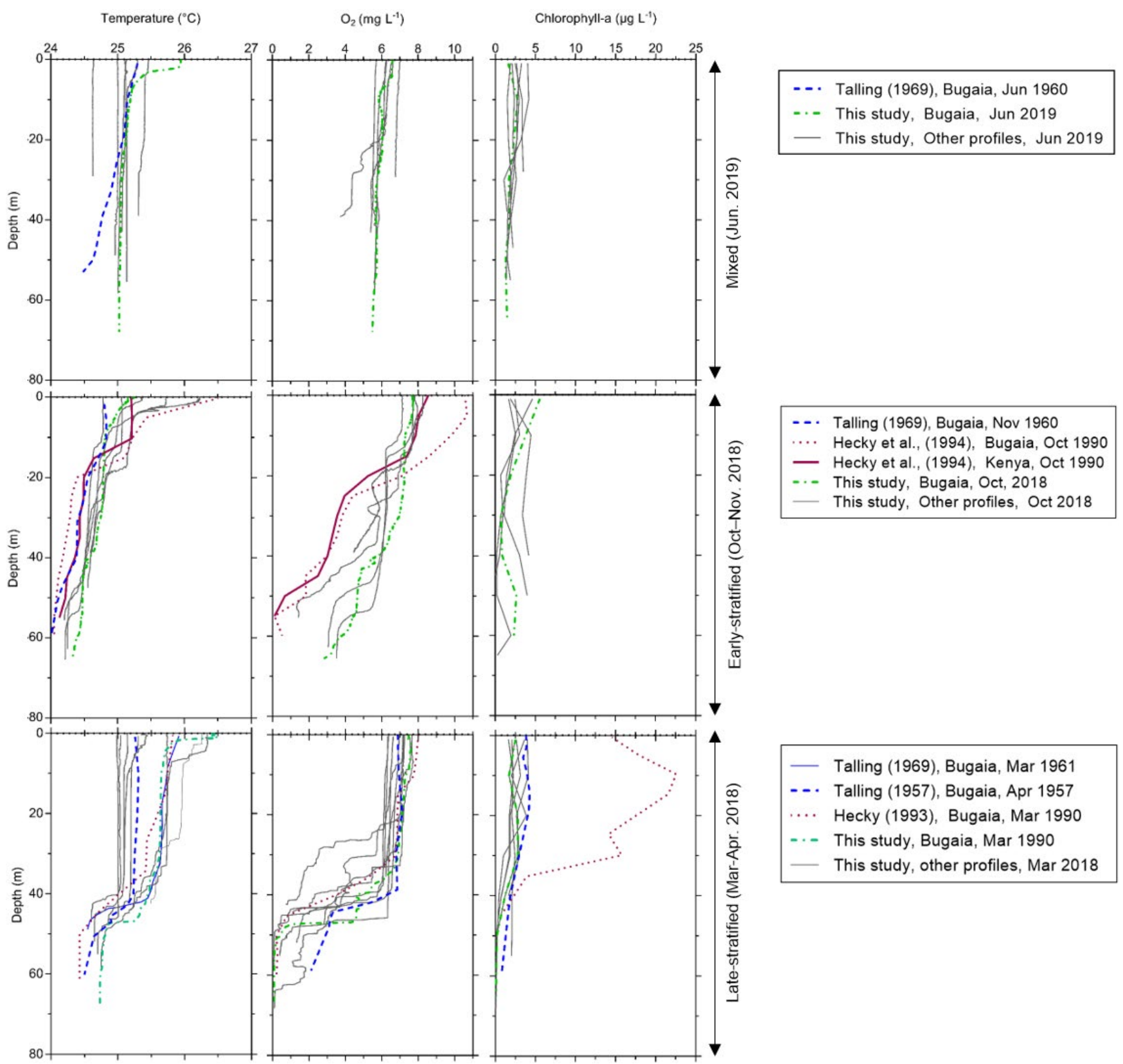

FIGURE 2 Vertical profiles during the different seasons (mixed vs. early-stratified vs. late-stratified periods) showing the water temperature $\left({ }^{\circ} \mathrm{C}\right)$, dissolved oxygen $(\mathrm{mg} / \mathrm{L})$ and chlorophyll-a concentrations ( $\left.\mu \mathrm{g} / \mathrm{L}\right)$. For comparison with historical data, Talling's historical station (UP2 as Bugaia; Figure 1) is highlighted in colour. Additional information on historical data is available in Table S4

Lehman, 2009). The long water residence time (c. 23 years) makes Lake Victoria susceptible to climate change and water quality deterioration (Akurut et al., 2017; Bootsma et al., 2003).

The general climate of the Lake Victoria basin ranges from a modified equatorial type to a semi-arid type (Anyah et al., 2006; Nicholson, 1996). The migration of the intertropical convergence zone has long been assumed to control seasonal variation in equatorial Africa but now this statement is challenged (Nicholson, 2018). The basin experiences yearly two rainy seasons: the short but heavy rainy season comes from March to May and the longer but low rainy season extends from August to November. There are 23 rivers flowing into the lake but only one effluent: the White, or Victoria Nile with an outflow of $20 \mathrm{~km}^{3} /$ year, approximately equivalent to the combined inflow from rivers (Bootsma et al., 2003; Lehman, 2009). The streams with the highest contribution of inflow into Lake Victoria basin are Kagera (32.7\%; average daily discharge $266 \mathrm{~m}^{3} / \mathrm{s}$ ) and Nzoia (14.6\%; $119 \mathrm{~m}^{3} / \mathrm{s}$ ) (Akurut, 2017). The water mass balance of Lake Victoria is thus largely dominated by the balance between rainfall input (+1525 mm/year) and evaporation output (-1539 mm/ year; Vanderkelen et al., 2018). The evaporative losses accounts for c. $80 \%$ of the water leaving the lake. Not only does evaporation represent a major water loss process in Lake Victoria, it is also a large 
heat budget component, and therefore plays an important role in the annual mixing regime, by means of evaporative cooling and turbulence (Bootsma et al., 2003). Precipitation also seems to play a role in carbon cycling, and provides a major source of dissolved organic matter (Deirmendjian, Lambert, et al., 2020). Thermal stratification is either absent or extremely modest from mid-May to mid-August, after which a definite stratification develops (Talling, 1957).

\section{2 | Sampling strategy and data availability}

To capture the seasonal variations of the studied parameters, sampling was conducted during three field campaigns that were characterised by three distinct hydrological conditions: in March 2018 (late-stratified and heavy rainy period, sampling was 29 March 2018-08 April 2018), October 2018 (early-stratified and low rainy period, 25 October 2018-04 November 2018) and June 2019 (mixed and dry period, 07 June 2018-17 June 2018). Sampling was carried out during day light (between 7 a.m. and 6 p.m.) in shallow nearshore sites $(23,15$, and 16 stations for the mixed, early-, and late-stratified seasons, respectively) to deeper offshore (7, 8, and 10) sites (Tables S1-S3; Figure 1). Additional data on sampling can be found in the publicly available database of the present paper (Deirmendjian, Descy, et al., 2020; Deirmendjian, Lambert, et al., 2020). The nearshore sampling sites were located in inner bays or outside the bays but close to the coastline. The water depth for these nearshore stations ranged from 8 to $31 \mathrm{~m}$ and the mean water depth was $13 \mathrm{~m}$. The offshore sites corresponded to sampling stations located in open waters off the several islands fringing the shore. The water depth for these offshore sampling stations ranged from 29 to $73 \mathrm{~m}$ and the mean water depth was $52 \mathrm{~m}$. At each sampling site, we carried out vertical profiles of inorganic $\left(\mathrm{NO}_{3}^{-} ; \mathrm{NO}_{2}^{-} ; \mathrm{NH}_{4}^{+}\right.$; soluble reactive phosphorus [SRP]) and particulate (particulate organic carbon [POC], particulate nitrogen [PN], and particulate phosphorus [PP]) nutrients (see Section 2.3) as well as phytoplankton composition and chlorophyll-a (see Section 2.4). The data set of vertical profiles contained 219 observations from the three sampling cruises $(77,68$, and 74 for the first, second, and third cruise, respectively). In addition, between each sampling station we performed continuous measurements of temperature in the surface waters (see section 2.3). After data processing, the data set of continuous measurements in surface waters contained 19,925 observations $(7,379,5,967$, and 6,579 observations from the first, second, and third cruise, respectively). Table S4 summarises sources of the historical data used in the study and their spatio-temporal representativeness and methodology.

\subsection{Water transparency, continuous measurements, and vertical profiles}

Secchi disk depth (SD) was determined at every sampling site with a homemade Secchi disk (30 cm diameter). The measurement was always read from the shaded side of the boat and by the same person. The vertical light attenuation coefficient in water $\left(\mathrm{k}, \mathrm{m}^{-1}\right)$ was derived at different sites during the third cruise in June 2019 from vertical profiles of photosynthetic active radiation (PAR) measured with an underwater quantum sensor (Li-COR Li-192) mounted on a Precision Measurement Engineering data logger (MiniPAR) attached to the CTD. $k$ is estimated from the slope of In $\left(\mathrm{PAR}_{z} / \mathrm{PAR}_{0}\right)$ against the depth $(z)$, where $\mathrm{PAR}_{z}$ and $\mathrm{PAR}_{0}$ are the PAR at a specific depth and at the surface, respectively. $k$ was related to SD (in $\mathrm{m}$ ) according to:

$$
k=1.4727 \times(1 / S D)-0.01\left(r^{2}=0.9\right)
$$

The measurements were done at 19 stations and were comparable to the historical data of Mugidde (1993) but covering a wider range of $k$ and SD than historical data (Figure S1). The general consistency of the chlorophyll- $a$ and SD between our data set and the one of Mugidde (1993) (Figure S2) suggests that observed differences between data sets do not result from methodological differences. The euphotic zone depth $\left(Z_{\text {eu }}\right)$, defined as the depth illuminated by $1 \%$ of incoming surface light, was then determined as:

$$
Z_{e u}=-\ln (0.01) / k
$$

At the scale of the entire lake, the slopes of the relationship between $Z_{\text {eu }}$ and SD in the present and past conditions are shown in the Figure S1.

Continuous measurements (data acquisition every $2 \mathrm{~min}$ ) of water temperature were carried out while traveling between sampling stations with a Yellow Springs Instrument (YSI) EXO-2 multiparameter probe. The probe was deployed on-deck in a bucket in which lake water was pumped with a submersible pump. At sampling stations, vertical profiles were made with the YSI EXO-2 probe that was slowly lowered on a rope with a data acquisition of $1 \mathrm{~s}$; only the downcast data were used, the upcast data were discarded. Calibration of sensors was carried out prior to the cruises and regularly checked during the cruises. The oxygen optical probe was calibrated with humidity saturated ambient air. Location was logged continuously by a Garmin GPS (Map 62). The water depth was recorded continuously with a Humminbird ${ }^{\circledR}$ echo sounder (Helix 5 G2). The depth of the mixed layer $\left(Z_{m}\right)$ was estimated as the top of the thermocline from CTD vertical profiles of temperature.

We carried out discrete vertical profiles of inorganic and particulate nutrients and total suspended matter (TSM) by using a 3-L Niskin bottle at a depth interval of $10 \mathrm{~m}$, from the lake surface (c. $1 \mathrm{~m}$ below the lake surface) to the lake bottom (c. $2 \mathrm{~m}$ above the lake sediment). For TSM, POC, PN, and PP a variable amount (150-1500 ml) of water was filtered at each sampling depth on a pre-combusted $25-\mathrm{mm}$ glass fibre filters for POC, PN, and PP (Sartorius GF5, $0.7 \mu \mathrm{m}$ nominal pore size) and on pre-weighed 47-mm glass fibre filters for TSM (Sartorius GF5, $0.7 \mu \mathrm{m}$ nominal pore size). Filters were dried, stored in the dark in plastic Petri dishes until analysis. TSM was determined by gravimetry. For POC and PN, the filters were decarbonated with $\mathrm{HCl}$ fumes for $4 \mathrm{hr}$, dried and packed in silver cups prior to analysis 
on an elemental analyser-isotopic ratio mass spectrometer (Thermo FlashHT with Thermo DeltaV Advantage). Relative standard deviation for POC and PN measurement were always below $\pm 5 \%$. PP was measured by spectrophotometry of phosphate using the molybdate blue-ascorbic acid reaction (APHA, 1998) after persulfate digestion (Valderrama, 1981). The molar C:N, C:P, N:P particulate ratios were used as indicators of phytoplankton nutrient status (Guildford et al., 2003). At each sampling depth, for dissolved inorganic nutrients, $50 \mathrm{ml}$ of water was filtered on a $0.2 \mu \mathrm{m}$ polyethylsulfone syringe filter and preserved frozen until measurement by colorimetry according to standard techniques. $\mathrm{NH}_{4}^{+}$concentration was determined using the dichloroisocyanurate-salicylate-nitroprussiate colorimetric method (Westwood, 1981). $\mathrm{NO}_{3}^{-}$and $\mathrm{NO}_{2}^{-}$were determined with the sulfanilamide colorimetric method, after cadmium reduction for $\mathrm{NO}_{3}^{-}$(APHA, 1998). SRP was determined by spectrophotometry using the ammonium molybdate-potassium antimony tartrate method (Murphy \& Riley, 1962). Samples for dissolved silica (DSi) were stored in 20-ml scintillation vials and preserved with $50 \mu \mathrm{l}$ of $\mathrm{HNO}_{3}$ (65\%). DSi was measured with inductively coupled plasma MS (ICP-MS; Agilent 7700x) calibrated with the following standards: SRM1640a from National Institute of Standards and Technology; TM-27.3 (lot 0412) and TMRain-04 (lot 0913) from Environment Canada; and SPS-SW2 Batch 130 from Spectrapure Standard. Limit of quantification was $8 \mu \mathrm{mol} / \mathrm{L}$ for DSi.

\section{4 | Pigments and phytoplankton diversity}

A variable volume of water (150-1500 ml) from each sampling depth (at a depth interval of $10 \mathrm{~m}$, from the lake surface to the lake bottom) was filtered on Macherey-Nagel 47-mm GF5 filters (nominal pore size $0.4 \mu \mathrm{m}$ ) on which pigment extraction was performed in 90\% high-performance liquid chromatography-grade acetone, following Sarmento et al. (2006). Phytoplankton biomass and composition were assessed throughout the study by determination of chlorophyll- $a$ and marker pigments by high-performance liquid chromatography using the Wright (1991) gradient elution method, with a Waters system comprising a photodiode array detector. Calibration was made using commercial external standards (Danish Hydraulic Institute, Denmark). For estimating phytoplankton abundance at the class level, pigment concentrations were processed with Chemtax software (Mackey et al. 1996) with a procedure similar to that of Descy et al. (2005) allowing estimating contribution to chlorophyll-a of green algae, chrysophytes, diatoms, cryptophytes, cyanobacteria, dinoflagellates, and euglenophytes, taking into account possible variation of pigment ratios with depth. The contribution of phytoplankton groups was expressed per unit volume ( $\mu$ g chlorophyll- $a / L$ ) or as percentage of total chlorophyll- $a$. We lumped the two pigment types of cyanobacteria, as the high taxonomic diversity of cyanobacteria in Lake Victoria (Kling et al., 2001; Lung'Ayia et al., 2000) does not allow to assign a pigment type to a particular taxon. In addition, the Chemtax processing could not separate diatoms and chrysophytes; however, as no chrysophytes were detected by microscopy in the lake samples, diatoms+chrysophytes could be safely considered as diatoms only.

Twenty-six 250-ml water samples were collected from $1 \mathrm{~m}$ depth and preserved with formaline ( $2 \%$ final concentration) for subsequent microscopic analyses. After settling to a final volume of $c$. $25 \mathrm{ml}$, the phytoplankton taxonomic biodiversity at species level was studied by conventional light microscopy with oil immersion 100x objective using LM microscope Motic BA 4000 considering modern algal taxonomy (Guiry \& Guiry, 2019; Komarek \& Hauer, 2020). Diatom samples were examined separately, using a $100 \times$ objective under phase contrast on a Leitz Diaplan standard microscope, after standard treatment of the settled suspension with hydrogen peroxide and slide mounting in Naphrax. Identification was carried out based on Krammer and Lange-Bertalot (1991, 1997a, 1997b, 2004), DiatomBase (Kociolek et al., 2020) and several recent references, in particular, Sitoki et al. (2013) for the needle-shaped Nitzschia. The algal occurrence in each sample was standardly estimated as rare, common, frequent, and dominant, based on the number of individuals. The general frequency of each alga was estimated as percent of number of samples in which they were found to the total number of collected samples.

\section{5 | Primary production}

Primary production rates were determined from photosynthesisirradiance incubations using $\mathrm{H}^{13} \mathrm{CO}_{3}^{-}$as a tracer for incorporation of DIC into biomass. A solution was freshly prepared before each measurement dissolving $5 \mathrm{mg}$ of $\mathrm{NaH}^{13} \mathrm{CO}_{3}$ with $500 \mathrm{ml}$ of surface water. Sub-samples of the ${ }^{13} \mathrm{C}$ spiked surface water sample were preserved in triplicate in 12-ml Exetainer vials and poisoned with a saturated solution of $\mathrm{HgCl}_{2}$ for the measurement of $\delta^{13} \mathrm{C}$-DIC at the onset of incubation; thereby determining the exact amount of ${ }^{13} \mathrm{C}$ tracer added. Eight $50-\mathrm{mL}$ polycarbonate flasks were filled with the spiked solution, and were placed into an incubator providing a range from $0 \%$ to $90 \%$ of natural light energy and incubated ondeck around mid-day for c. $2 \mathrm{hr}$ at constant temperature. A Li-Cor quantum sensor (LI-190; 5-min interval acquisition) monitored incident light for the entire duration of the cruises. The incubation was stopped by adding neutral formaldehyde ( $1 \%$ final concentration) and water samples were filtered on pre-combusted MachereyNagel GF5 filters (25 mm diameter). The specific photosynthetic rate in an individual bottle i, $\mathrm{Pi}$ (in $\mu \mathrm{g} \mathrm{C} \mathrm{L}^{-1} \mathrm{hr}^{-1}$ ), was calculated following Hama et al. (1983) based on initial and final $\delta^{13} \mathrm{C}$-POC values and $\delta^{13} \mathrm{C}$-DIC of the spiked incubated solution. For each experiment, the maximum specific photosynthetic rate $P_{m}$ (in $\mu g C^{-1} \mathrm{hr}^{-1}$ ) and the irradiance at the onset of light saturation $I_{k}\left(\mu E m^{-2} s^{-1}\right)$ were determined by fitting $\mathrm{Pi}$ to the irradiance gradient provided by the incubator li $\left(\mu \mathrm{E} \mathrm{m}^{-2} \mathrm{~s}^{-1}\right.$ ), using the equation given by Vollenweider (1965). Fitting was performed using the Gauss-Newton algorithm for nonlinear least squares regression with the JMP® software. Daily depth-integrated primary production (PP daily in $\mathrm{mg} \mathrm{C}^{-2} \mathrm{~d}^{-1}$ ) was determined assuming a vertically homogenous chlorophyll- $a$ 
profile over the euphotic zone with the photosynthetic parameters $P_{\mathrm{m}}$ and $I_{\mathrm{k}}$, the extinction coefficient $k$, and continuous surface irradiance data (Kirk, 1994). These measurements were integrated from averaged daily surface irradiance during the cruise. In addition, we defined the average light experienced by the phytoplankton in the mixed layer $\left(I_{\mathrm{Zm}}\right)$ according to Riley (1957):

$$
I_{Z m}=I_{s}\left(1-\exp \left(-Z_{m} k\right)\right) / Z_{m} k
$$

where $I_{\mathrm{s}}$ is the mean incident light at the surface of the lake during the entire cruises and measured with a Li-Cor quantum sensor. The sensor continuously recorded light throughout the day during the entire cruises and then we estimated a mean light for the daylight.

Prior to the analysis of $\delta^{13} \mathrm{C}$-DIC, a 2-ml helium headspace (He) was created, and $100 \mu \mathrm{l}$ of phosphoric acid $\left(\mathrm{H}_{3} \mathrm{PO}_{4}, 99 \%\right)$ was added in the vial in order to convert all inorganic $\mathrm{C}$ species to $\mathrm{CO}_{2}$. After overnight equilibration, a subsample of the headspace was injected with a gastight syringe into an elemental analyser-isotopic ratio mass spectrometer (Thermo FlashHT with Thermo DeltaV Advantage). The obtained data were corrected for isotopic equilibration between dissolved and gaseous $\mathrm{CO}_{2}$ as described in (Gillikin \& Bouillon, 2007). Calibration of $\delta^{13} \mathrm{C}$-POC measurements was performed with a combination of IAEA-600 (caffeine, $\delta^{13} \mathrm{C}=-27.77 \%$ ) and two in-house standards, leucine and tuna tissue $\left(\delta^{13} \mathrm{C}=-13.47\right.$ and $-18.72 \%$, respectively). Reproducibility of $\delta^{13} \mathrm{C}$-POC measurements was typically better than $\pm 0.2 \%$.

\subsection{Southern Oscillation Index, wind, and air temperature data}

For the 1981-2019 period, monthly averages of wind speed and air temperature over Lake Victoria $\left(0.6^{\circ}\right.$ to $-3^{\circ} \mathrm{N}$ and $31.4^{\circ}$ to $\left.34.3^{\circ} \mathrm{E}\right)$ were retrieved from the European Center for Medium Weather Forecast (ECMWF) Reanalysis version 5 (ERA5) dataset $(30 \mathrm{~km}$ resolution) (Hersbach et al., 2020). For the same time-period, we retrieved the smoothed Southern Oscillation Index (SOI) from the National Center for Atmospheric Research at https://climatedataguide.ucar.edu/climate-data/southern-oscillation-indices-signal-noise -and-tahitidarwin-slp-soi (Schneider et al., 2013). Negative SOI value is indicative of prevailing El Niño conditions whereas positive SOI is indicative of prevailing La Niña conditions.

\section{3 | RESULTS}

\section{1 | Stratification cycle in Lake Victoria in 2018- 2019 and comparison with historical observations}

In the offshore waters, the water column of Lake Victoria was isothermal in June 2019 (i.e. mixed season) whereas we observed weak thermal stratification in October-November 2018 (i.e. earlystratified season) and the appearance in March-April 2018 (i.e. late-stratified season) of stronger thermal gradients (Figure 2). Average $Z_{\mathrm{m}}$ in offshore stations was 49,32 , and $33 \mathrm{~m}$, during the mixed, early-stratified, and late-stratified seasons, respectively (Tables S1-S3; Figure 3). In 2018-2019, thermal gradients in the offshore waters, estimated as the difference in temperature between surface $(0-20 \mathrm{~m})$ and deep $(40-68 \mathrm{~m})$ waters, were $0.04,0.60$, and $0.63^{\circ} \mathrm{C}$ during the mixed, early-stratified, and late-stratified seasons, respectively (Tables S1-S3).

Although we did not monitor the lake's water column thermal structure during an entire year, our observations agree with those made by Talling (1966) during the years 1960-1961, which distinguished three phases of stratification in Lake Victoria. Talling (1966) showed that the first stratification phase was from September to December and was characterised by the appearance of small thermal gradients. During this period Ssebuggwawo et al. (2005) observed that almost total vertical mixing may occur at some offshore stations in the December-January period. The second phase was the development of the deep thermocline in the period February-May, which was located at 40-50 m depth in the 1960s and at 30-40 m depth in the 1990s (Hecky, 1993; Talling, 1966; Figure 2). Notably, in the latestratified season of 2018-2019, the thermocline of most sampling stations was located at 40-50 m depth (Figure 2). The third phase, between June and August was marked by the absence of thermal stratification and thus by the total vertical mixing of the water column (Figure 2). Vertical mixing in Lake Victoria may be initiated by increased south-eastern monsoon winds, which cause the thermocline to upwell with concomitant mixing, but deep mixing due to heat loss by evaporation is ultimately responsible (Maclntyre, 2013). The mixed season corresponds indeed to the windiest (average of $1.5 \pm 0.5 \mathrm{~m} / \mathrm{s}$ during the 1981-2019 period) period over Lake Victoria, statistically ( $p<0.05$, Mann-Whitney test) higher than the early- $(0.7 \pm 0.2 \mathrm{~m} / \mathrm{s})$ and late- $(1.3 \pm 0.5 \mathrm{~m} / \mathrm{s})$ stratified seasons (Figure S3). However, the wind starts to increase in April and May (Figure S3), which can be considered as the beginning of the destratification period (Mwirigi et al., 2005). In addition, since the 2000s, we have observed an increasing trend of wind speed over the lake, which was positively correlated with the SOI (Figure 4, Figures S3 and S4).

\section{2 | Overview of ecological conditions in Lake Victoria in the late 2010s}

Irrespective of the seasons, oxygen saturations in the surface offshore waters were close to atmospheric equilibrium (Table 1 ). In offshore sites, oxygen concentrations ranged 4.5-8.9 and 0.1-6.3 mg/L in surface and deep waters, respectively (Tables S1-S3). In the offshore waters, oxygen vertical gradients (i.e. difference of oxygen concentrations between surface and deep waters) were 0.6, 3.8, and $5.5 \mathrm{mg} / \mathrm{L}$ during the mixed, early-stratified, and late-stratified seasons, respectively (Table 1 ). In inshore sites, oxygen concentrations ranged 0.8-9.2 $\mathrm{mg} / \mathrm{L}$ in the 0-20 $\mathrm{m}$ layer (Tables S1-S3).

Irrespective of the seasons, $Z_{\text {eu }}$ was significantly $(p<0.001$, MannWhitney test) higher at offshore $(11.4 \mathrm{~m})$ than inshore $(5.5 \mathrm{~m})$ sites 

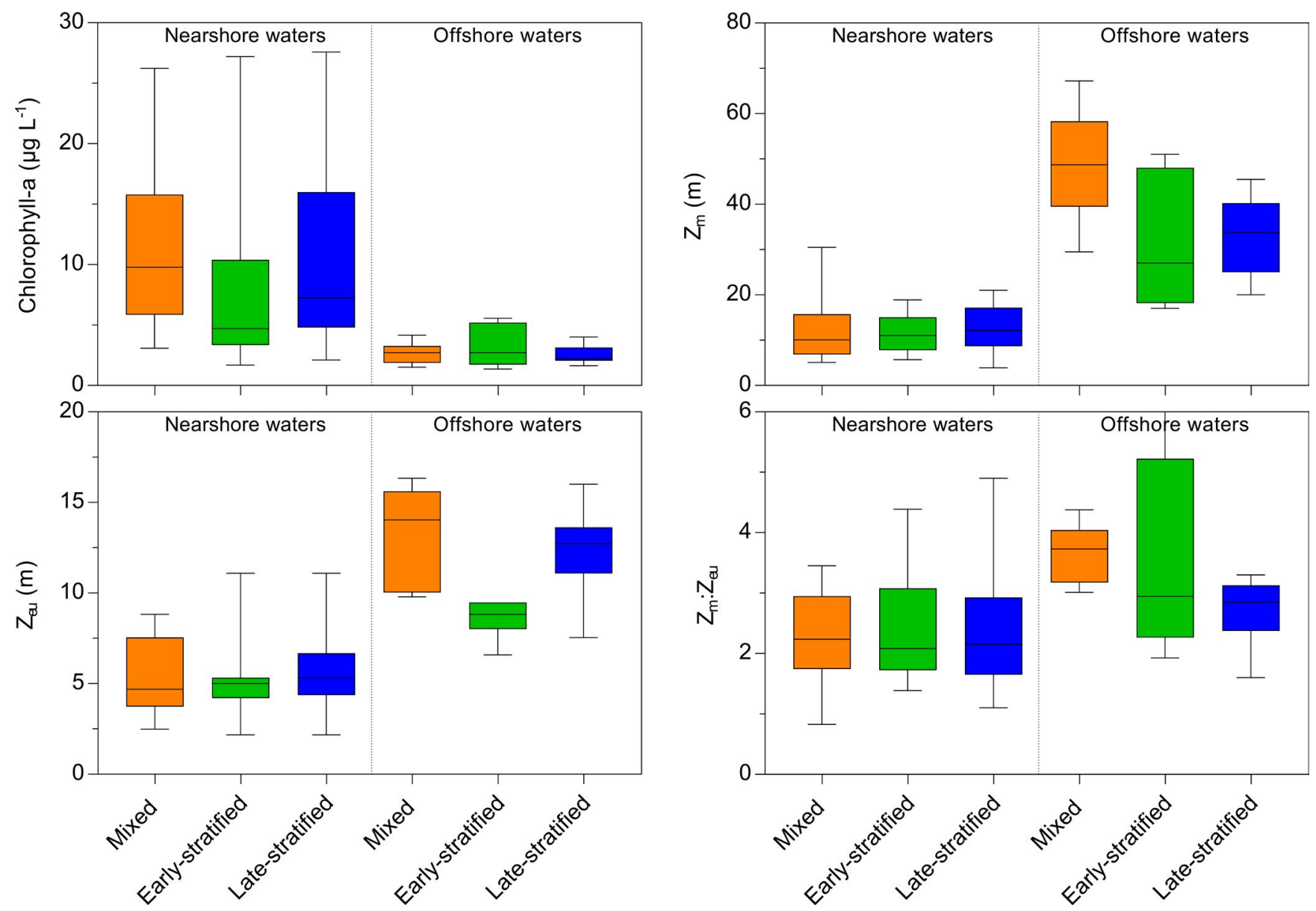

FIGURE 3 Seasonal (mixed vs. early-stratified vs. late-stratified periods) and spatial (nearshore vs. offshore waters) variations in the euphotic layer of chlorophyll- $a(\mu \mathrm{g} / \mathrm{L}), Z_{\mathrm{eu}}(\mathrm{m}), Z_{\mathrm{m}}(\mathrm{m})$, and $Z_{\mathrm{m}}: Z_{\mathrm{eu}}$

(Table 2). In contrast, both $I_{\mathrm{k}}$ and $I_{-z \mathrm{~m}}$ in surface waters were similar at offshore (296 and $62 \mu \mathrm{E} \mathrm{m}^{-2} \mathrm{~s}^{-1}$ for $I_{\mathrm{k}}$ and $I_{\mathrm{zm}}$, respectively) and inshore ( 312 and $83 \mu \mathrm{E} \mathrm{m}^{-2} \mathrm{~s}^{-1}$ ) sites (Table 2). In the nearshore and offshore waters, the ratio $I_{\mathrm{k}}: I_{\mathrm{zm}}$ ranged between 3 and 6 (Tables S1-S3). Spearman's rank correlation tests indicated that POC, TSM, and chlorophyll- $a$ were all negatively correlated with $k$ but with higher correlation coefficients for POC and TSM than for chlorophyll- $a(r=-0.95,-0.90$, and -0.76 , for POC, TSM, and chlorophyll- $a, p<0.0001, n=52-54$, data not shown).

In the surface waters at nearshore sites nutrient concentrations were $1.6 \pm 1.5,3.2 \pm 4.8,0.6 \pm 0.8$, and $31 \pm 15 \mu \mathrm{mol} / \mathrm{L}$ for $\mathrm{NO}_{3}^{-}$, $\mathrm{NH}_{4}^{+}$, SRP, and DSi, respectively (Table 2). In the surface waters at offshore sites nutrient concentrations were $2.0 \pm 1.9,3.0 \pm 5.0,1.1 \pm 0.2$, and $36 \pm 6 \mu \mathrm{mol} / \mathrm{L}$ for $\mathrm{NO}_{3}^{-}, \mathrm{NH}_{4}^{+}, \mathrm{SRP}$, and DSi, respectively (Table 2). According to Guildford et al. (2003), our data from 2018-2019 on the C:N particulate ratio (mean range of 8.0-10.6; up to 20.4 in the offshore waters during the stratified season, Figure 5) indicate a moderate $\mathrm{N}$-limitation of phytoplankton growth in 2018-2019 (especially during the late-stratified season; Figure 5). Also, the N:P particulate ratio in 2018-2019 always below 20 irrespective of the seasons indicated that primary production did not seem limited by P in 2018-2019 (Figure 5).

Irrespective of the seasons, PP daily in surface waters was twice higher at nearshore $\left(0.9 \pm 0.6 \mathrm{~g} \mathrm{C} \mathrm{m}^{-2} \mathrm{day}^{-1}\right)$ than offshore $(0.5 \pm 0.3 \mathrm{~g}$ $\mathrm{C} \mathrm{m}^{-2}$ day $^{-1}$ ) sites (Table 2). Seasonally, PP daily was twice higher in the mixed season when inorganic $N$ in surface waters was higher than in the early- and late-stratified seasons (Tables S1-S3, Figure S5). Chlorophyll- $a$ concentrations were $10.3 \pm 7.1$ (range 0.4-27.2) and $2.8 \pm 1.1(0.7-5.6) \mu \mathrm{g} / \mathrm{L}$ in the nearshore and offshore surface waters, respectively (Table 2; Figure 3 ). The measurements of chlorophyll- $a$ in the offshore waters did not indicate seasonal maxima, as chlorophyll- $a$ concentration was similar ( $p>0.05$, Kruskal-Wallis test) among seasons although the range was higher in the early-stratified season (Tables S1-S3; Figure 3). Based on the slope of the linear regression of chlorophyll-a against POC (Figure S6), we determined C:chlorophyll- $a$ ratios of 85 and 103 in the nearshore and offshore waters, respectively. Applying these ratios to chlorophyll- $a$ concentration shows that phytoplankton biomass accounted on average for $40 \%$ of the POC; in other words, a major fraction of the POC (c. $60 \%$ ) was non-phytoplankton carbon (detrital or microbial; Figure S6).

\subsection{Historical changes in chlorophyll- $a$ and photosynthesis}

Historical data indicated that chlorophyll- $a$ surface water concentrations were relatively low in the 1960s (on average 13 and $3 \mu \mathrm{g} / \mathrm{L}$ in the nearshore and offshore waters, respectively, Table 2) with the 

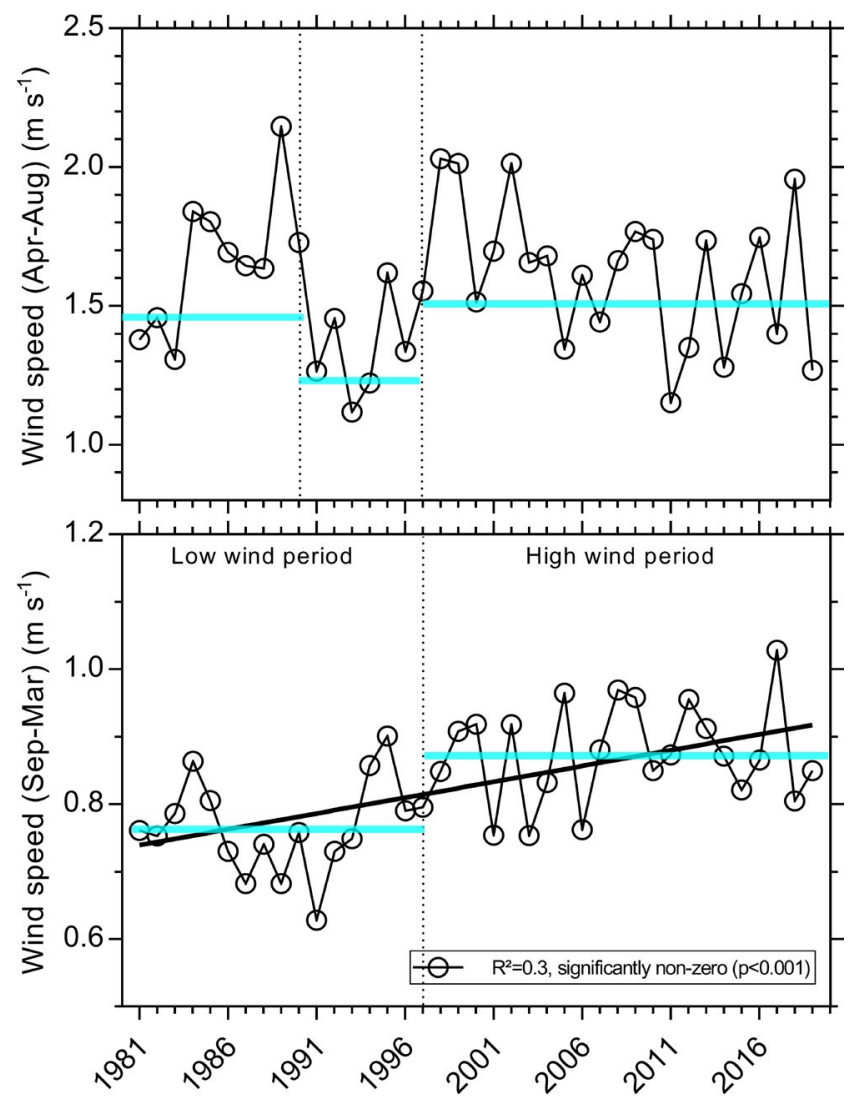

FIGURE 4 Monthly wind speed data retrieved from the ERA5 satellite (Hersbach et al., 2020) for the 1981-2019 period. The blue lines indicated the mean of a given period, which are defined by the vertical dashed lines. The dashed lines in 1991-1997 correspond to the period of low wind stress notably observed during Hecky's and Muggide's studies. The linear regression for the September to March period is $Y=0.004984^{*} X+0.8324$ and $r^{2}=0.3$. The slope is significantly non-zero $(p<0.001)$

barely detectable $\mathrm{NO}_{3}^{-}$concentrations, suggesting $\mathrm{N}$-limitation of primary production (Talling, 1965, 1966). Chlorophyll-a concentrations increased considerably between the 1960s and the 1990s, and it was one of the main indicators of eutrophication of Lake Victoria (Hecky, 1993). Chlorophyll-a concentrations increased by a factor $>4$ (71 and $14 \mu \mathrm{g} / \mathrm{L}$, in the nearshore and offshore waters, respectively, Table 2 ) in the 1990 s and this has probably been caused by bottomup effects of excess nutrient loading in the lake (Hecky, 1993; Hecky et al., 2010; Stager et al., 2009; Verschuren et al., 2002). In addition, based on data collected in the late 1990s, Guildford et al. (2003) showed that the C:P, C:N, and N:P particulate ratios in Lake Victoria were initially at or below levels indicating $\mathrm{N}$ or $\mathrm{P}$ deficiency, showing that the lake phytoplankton was at that time controlled by a factor other than $\mathrm{N}$ or $\mathrm{P}$ in situ. In the 1990s, the lake phytoplankton was usually light-limited because of self-shading (low transparency) due to high chlorophyll-a concentrations (Table 2; Mugidde et al., 2003; Silsbe et al., 2006). Approximately a decade after Hecky (1993), data collected during lake-wide surveys campaigns in 2000-2005 showed a decline in chlorophyll-a concentrations in comparison with the 1990s, as chlorophyll-a concentration was 4-12 $\mu \mathrm{g} / \mathrm{L}$ in the offshore waters (Gikuma-Njuru et al., 2005). However, in the mid-2000s, some authors still measured locally high concentrations of chlorophyll- $a$ in inner bays: Silsbe et al. (2006) and Mwirigi et al. (2005) measured values up to 70 and $111 \mu \mathrm{g} / \mathrm{L}$, in Murchison Bay and Mwanza Gulf, respectively. In contrast, the highest values of chlorophyll-a measured in Napoleon Gulf in 2018-2019 was $28 \mu \mathrm{g} / \mathrm{L}$ (Table S1-S3, Figure 3).

The most significant result of the present study is the even larger decline of chlorophyll-a concentrations in comparison with the situation observed during the early 2000 s, with average concentrations closer to those measured in the 1960 s by Talling $(1965,1966)$ (Table 2, Figures 2 and 3). Accordingly, vertical profiles of chlorophyll- $a$ concentrations at Talling's historical station showed a similarity between present conditions and those observed in the 1960s, while the vertical profiles of 1990s stand clearly higher (Figure 2). The overall consistent relationship between chlorophyll- $a$ and SD from our data set and those from the 1990s and 2000s (Figure S2) suggests that chlorophyll- $a$ data sets are comparable and differences do not result from methodological inconsistencies. In the nearshore and offshore waters, primary production decreased by a factor of $c$. 7-8 between the early 1990s and late 2000s (Table 2). This agrees with the fact that chlorophyll-a concentrations decreased by a factor of c. 6-7 during the same period while the photosynthetic capacity, $P_{\text {max }}$, remained similar (Table 2). The generalised and consistent decrease of chlorophyll- $a$ and primary production in both offshore and nearshore stations suggests that the change is driven by changes in light availability rather than nutrient availability, since changes in nutrients would have been expected to be more pronounced in nearshore than offshore waters.

\section{4 | Phytoplankton composition in Lake Victoria in the late 2010s and comparison with historical observations}

The most abundant phytoplankton groups in the lake were cyanobacteria ( $>60 \%$ of chlorophyll- $a$ in mixed and early-stratified conditions), followed by diatoms, which presented the highest contribution in late-stratified condition (Figure 6). Green algae and the other phytoplankton groups were much less developed (Figure 6). In terms of diversity, we identified a total of 302 phytoplankton taxa, including 99 taxa of Cyanoprokaryota, 156 taxa of green algae, and 40 taxa of Ochrophyta (mostly diatoms; data not shown). Notably, despite green algae presenting much lower abundance, they exhibited a rather large diversity, with essentially nonmotile forms, particularly in the inshore waters, as also observed in the nearby Lake Edward by Stoyneva-Gärtner et al. (2020). Microscopic examinations revealed that the most frequent cyanobacterial taxa were coccal colonial forms, such as Snowella lacustris, Microcystis wesenbergii, and Aphanocapsa koordersii, as well as the filamentous non-heterocystous Planktolyngbya circumcreta and Planktolyngbya tallingii (50\%), all five species present in $>50 \%$ 
TABLE 1 Historical trend of temperature $\left({ }^{\circ} \mathrm{C}\right)$ and oxygen $(\mathrm{mg} / \mathrm{L})$ in Lake Victoria in the surface and bottom waters

\begin{tabular}{|c|c|c|c|c|c|c|}
\hline Temperature $\left({ }^{\circ} \mathrm{C}\right)$ & & & \multicolumn{2}{|c|}{ Surface (0-1 m deep) } & $>50 \mathrm{~m}$ deep & Difference \\
\hline \multirow{4}{*}{ Yearly average } & \multicolumn{2}{|c|}{ 2000-2005 (LVEMP surveys) } & \multicolumn{2}{|c|}{$24.96 \pm 0.59$} & $23.32 \pm 0.29(27)$ & 1.37 \\
\hline & \multicolumn{2}{|l|}{2008 (IFMP surveys) } & \multicolumn{2}{|c|}{$25.68 \pm 0.83(89)$} & $24.66 \pm 0.23(35)$ & 1.02 \\
\hline & \multicolumn{2}{|l|}{2009 (IFMP surveys) } & \multicolumn{2}{|c|}{$25.88 \pm 0.86(108)$} & $24.89 \pm 0.23(30)$ & 0.99 \\
\hline & 2018-2019 (This study) ${ }^{b, c}$ & & 25.72 & $69(19,925)$ & $24.68 \pm 0.06(2,495)$ & 0.84 \\
\hline \multicolumn{2}{|l|}{ Oxygen (mg/L) } & \multicolumn{2}{|c|}{$\begin{array}{l}\text { Surface }(0-5 \mathrm{~m} \\
\text { deep) }\end{array}$} & $>40$ m deep & Difference & $\begin{array}{l}\text { Oxygen saturation } \\
\text { (0-1 m deep; \%) }\end{array}$ \\
\hline \multirow[t]{2}{*}{ Mixed season } & 1960-1961 (Talling, 1966) & & & $6.0 \pm 0.3$ & 0.9 & $\begin{array}{l}94 \\
111\end{array}$ \\
\hline & 2018-2019 (This study) & \multicolumn{2}{|c|}{$6.3 \pm 0.4$ (699) } & $5.7 \pm 0.1(1,130)$ & 0.6 & $89(88)$ \\
\hline \multirow{3}{*}{$\begin{array}{l}\text { Early-stratified } \\
\text { season }\end{array}$} & 1960-1961 (Talling, 1966) & & & $3.5 \pm 0.4$ & 3.5 & 97 \\
\hline & 1990-1991 1991 (Hecky et al., 1994) & \multicolumn{2}{|c|}{$8.1 \pm 1.3$} & $1.5 \pm 1.1$ & 6.6 & 126 \\
\hline & 2018-2019 (This study) & & $(1,560)$ & $4.1 \pm 1.2(1599)$ & 3.8 & $107(344)$ \\
\hline Late-stratified & 1960-1961 (Talling, 1966) & & & $4.1 \pm 1.1$ & 1.9 & 93 \\
\hline season & 1990-19911991 (Hecky et al., 1994) & & & $2.7 \pm 1.8$ & 4.4 & 110 \\
\hline & 2000-2001 (LVRFP surveys) & & (36) & $2.6 \pm 3.7(36)$ & 5.2 & \\
\hline & 2006-2009 (IFMP surveys) & & (45) & $6.1 \pm 1.8(45)$ & 1.2 & \\
\hline & 2018-2019 (This study) & & $(2,231)$ & $1.7 \pm 1.7(3,087)$ & 5.5 & 99 (826) \\
\hline
\end{tabular}

Note: Temperature data in 1927 are from Graham (1929). Temperature data in 2000-2005 were retrieved from table 3 in Mwirigi et al. (2005) and data are from Lake Victoria Environmental Management Project. Temperature data in 2000, 2008 and 2009 were retrieved from table 1 in Sitoki et al., (2010) and from table 1 in Marshall et al. (2013). These data were obtained during acoustic surveys of fish during the Lake Victoria Fisheries Research Project and the Implementation of a Fisheries Management Plan. Oxygen data in 1960-1961 and 1990-1991 are from Talling (1966) and Hecky et al. (1994) and were retrieved from table 1 in Hecky et al., (1994). Oxygen data in 2000-2001 and 2006-2009 were retrieved from table 2 in Sitoki et al., (2010) and comes from Lake Victoria Fisheries Research Project and the Implementation of a Fisheries Management Plan surveys. All data originates from lake-wide surveys except data from Talling (1966) and Hecky et al., (1994), which are from Talling's Historical station (UP2 in Figure 1). Additional information on the historical data are in Table S4. In 2018-2019, the number of measures is indicated between brackets.

${ }^{a}$ Calculated from vertical profiles of temperature in the offshore waters.

${ }^{b}$ Yearly-integrated value considering that our measurements carried out in June, October, and March 2018-2019 are representative of the different stratification phases (3, 4, and 5 months for the mixed, early-, and late-stratified seasons) observed by Talling (1966).

${ }^{c}$ Calculated from continuous measurements of temperature in surface waters, thereby both including nearshore and offshore waters.

of the samples. Heterocystous cyanobacteria were better represented in the nearshore waters (mainly Dolichospermum spp., with some Raphidiopsis [= Cylindrospermopsis spp.]) than in the offshore waters (Dolichospermum sp. only), where they occurred rarely. The present diatom assemblage appears dominated by Nitzschia spp. but Aulacoseira and Cyclostephanos are still found in the nearshore and offshore waters. Besides, the diversity of diatoms was presently higher in the nearshore waters, due to the contribution of taxa of benthic origin. The planktonic taxa found in the nearshore waters were also found in the offshore waters, albeit with different abundance; most notably, of the four Aulacoseira species found nearshore, only one, Aulacoseira granulata var. angustissima, was observed offshore, in much lower abundance. The most conspicuous taxa well developed offshore were long, needle-shaped Nitzschia (chiefly Nitzschia rusingae and Nitzschia kavirondoensis, corresponding pro parte to the Nitzschia acicularis recorded in the sediments and in the water column, as revisited by Sitoki et al., [2013]), Nitzschia lacuum, Synedra cunningtonii, and Cyclostephanos spp.

In the 1960s, the estimates of chlorophyll- $a$ indicated two seasonal maxima in phytoplankton biomass, in December to February (late-stratified season) and in August (mixed season) (Talling, 1966). The diatom Melosira (now Aulacoseira) maximum during the mixed season was followed by the annual cyanobacteria Anabena (now Dolichospermum) maximum, which was briefly prominent during early stratification when thermal gradients were found throughout the water column (Talling, 1966). In contrast, Hecky (1993) reported minimum phytoplankton biomass in July-August when the lake mixed throughout its depth. High biomass of $\mathrm{N}_{2}$-fixing cyanobacteria was re-established after 
TABLE 2 Historical changes in the nearshore and offshore waters of particulate nutrients $(\mathrm{PN}, \mathrm{POC}, \mathrm{PP})$, inorganic nutrients $\left(\mathrm{NO}_{3}^{-}, \mathrm{NH}_{4}^{+}\right.$, SRP, DSi), physical and light conditions $\left(Z_{e u}, Z_{m}, k, I_{k}, I_{z m}\right.$, Secchi depth) and chlorophyll- $a$ and primary production

\begin{tabular}{|c|c|c|c|c|c|c|}
\hline & \multicolumn{2}{|l|}{1960} & \multicolumn{2}{|l|}{1990} & \multicolumn{2}{|l|}{ 2018-2019 } \\
\hline $\mathrm{POC}(\mu \mathrm{mol} / \mathrm{L})$ & & & $232(104)$ & $138(24)$ & $166 \pm 104(54)$ & $63 \pm 27(33)$ \\
\hline $\mathrm{PN}(\mu \mathrm{mol} / \mathrm{L})$ & & & $33.2(97)$ & $10.6(24)$ & $20.0 \pm 13.4(54)$ & $6.5 \pm 2.1(33)$ \\
\hline $\mathrm{PP}(\mu \mathrm{mol} / \mathrm{L})$ & & & $1.4(205)$ & $0.5(24)$ & $2.0 \pm 1.4(49)$ & $0.7 \pm 0.4(28)$ \\
\hline $\mathrm{NH}_{4}^{+}(\mu \mathrm{mol} / \mathrm{L})$ & & & $3.4 \pm 4.5(58)$ & $1.5 \pm 1.1(28)$ & $3.2 \pm 4.8(51)$ & $3.0 \pm 5.0(29)$ \\
\hline $\operatorname{SRP}(\mu \mathrm{mol} / \mathrm{L})$ & & & $0.9 \pm 1.2(58)$ & $1.5 \pm 1.0(39)$ & $0.6 \pm 0.8(50)$ & $1.1 \pm 0.2(33)$ \\
\hline DSi $(\mu \mathrm{mol} / \mathrm{L})$ & 74 & 66 & 10 & 25 & $31 \pm 15$ (33) & $36 \pm 6(23)$ \\
\hline Secchi depth (m) & & & $1.5 \pm 0.4(22)$ & $2.4 \pm 0.6(23)$ & $1.7 \pm 0.6(53)$ & $3.6 \pm 0.9(24)$ \\
\hline$I_{k}\left(\mu E m^{-2} s^{-1}\right)$ & & & $130 \pm 76(32)$ & $108 \pm 41(18)$ & $312 \pm 83(13)$ & $296 \pm 77(12)$ \\
\hline$I_{z m}\left(\mu E m^{-2} s^{-1}\right)$ & & & $217 \pm 13(12)$ & $108 \pm 45(12)$ & $83 \pm 34(13)$ & $62 \pm 20(12)$ \\
\hline$P_{\max }\left(\mathrm{mg} \mathrm{C}\right.$ mg Chl-a $\left.{ }^{-1} \mathrm{hr}^{-1}\right)$ & & & $5.4 \pm 1.8$ & $5.7 \pm 1.8(12)$ & $5.6 \pm 2.4(13)$ & $4.3 \pm 2.2(12)$ \\
\hline PP daily ( $\mathrm{g} \mathrm{C} \mathrm{m}^{-2}$ day $^{-1}$ ) & $3.1 \pm 3.3(4)$ & $2.2 \pm 0.6(4)$ & $6.0 \pm 2.1(13)$ & $3.9 \pm 1.2(12)$ & $0.94 \pm 0.57(13)$ & $0.50 \pm 0.25(12)$ \\
\hline Chlorophyll- $a$ ( $\mu \mathrm{g} / \mathrm{L})$ & 13 & 3 & $71 \pm 100(47)$ & $13.5 \pm 5.8(42)$ & $10.3 \pm 7.1(55)$ & $2.8 \pm 1.1(34)$ \\
\hline
\end{tabular}

Note: Data from 1960 are from Talling (1965); data from 1990 are from Mugidde (1992), Mugidde (2001), and Mugidde et al., (2003); data from 2018-2019 are from this study. Concentrations are for the euphotic layer. Number of samples are between brackets (when available). Additional information on the historical data are in Table S4. Note that we converted $P_{\max }$ and PP daily values measured by Mugidde (1993) and Talling (1965) with a conversion factor of 3.33 (which is 1.25 mole of $\mathrm{O}_{2}$ produced per mole of $\mathrm{C}$ fixed).
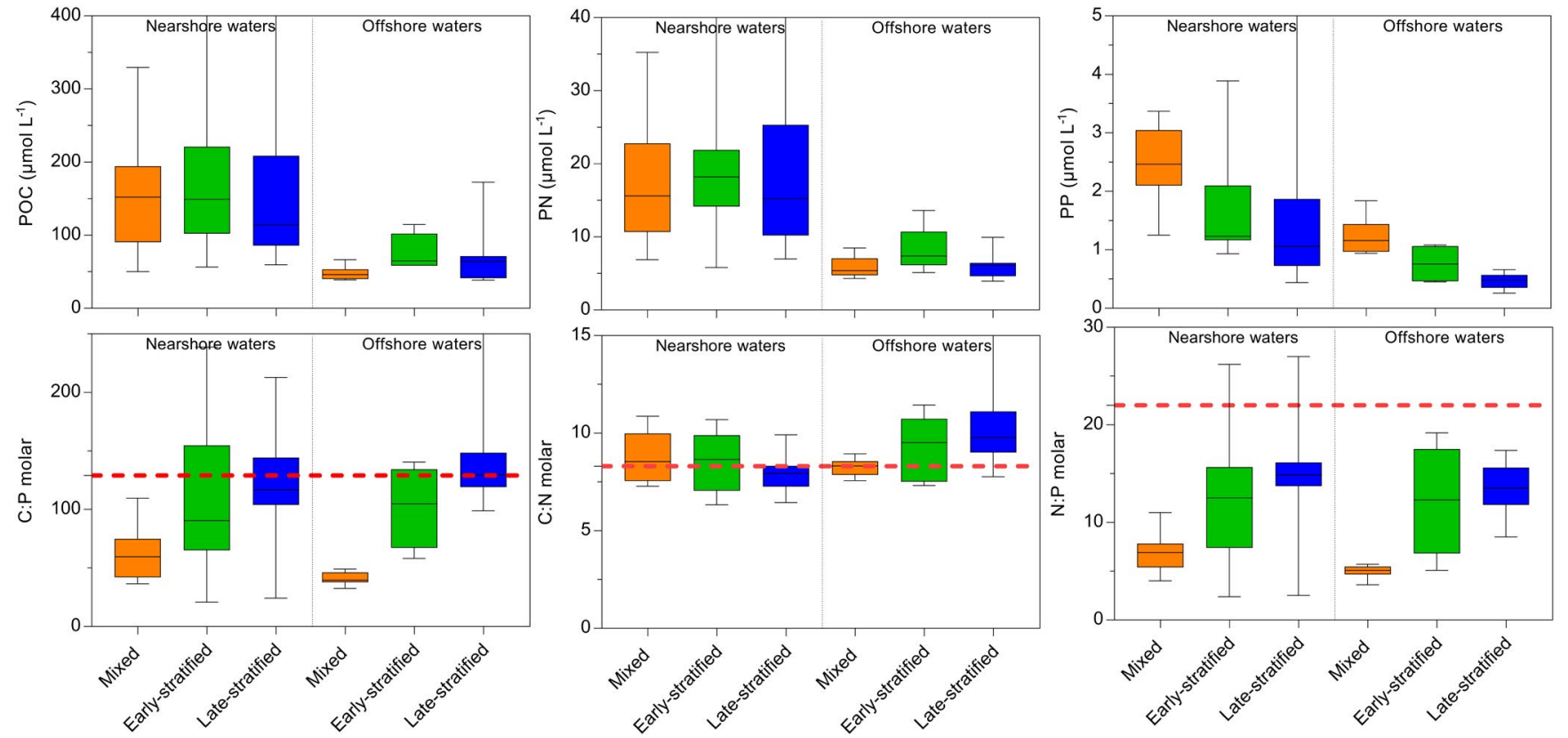

FIGURE 5 Seasonal (mixed vs. early-stratified vs. late-stratified periods) and spatial (nearshore vs. offshore waters) variations in the euphotic layer of particulate organic carbon (POC; $\mu \mathrm{mol} / \mathrm{L}$ ), particulate nitrogen (PN; $\mu \mathrm{mol} / \mathrm{L}$ ), particulate phosphorous (PP; $\mu \mathrm{mol} / \mathrm{L}$ ), and molar ratios of C:P, C:N, N:P. The red dashed lines indicated the degree of nutrient deficiency according to Guildford et al. (2003)

re-stratification in September and the annual biomass maximum occurred in the 1990 s during the stratified season. In the 1990s,
Aulacoseira had declined, being excluded by the low DSi concentrations (Table 1; Figure 7) and the low TN:TP ratio favouring 
Nearshore waters in the mixed season

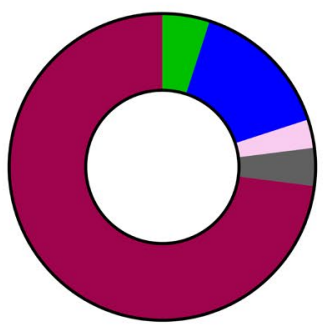

Green Algae 5\%

- Diatoms 15\%

- Euglenophytes 3\%

- Cryptophytes 4\%

- Cyanobacteria $73 \%$

Nearshore waters in the early-stratified season

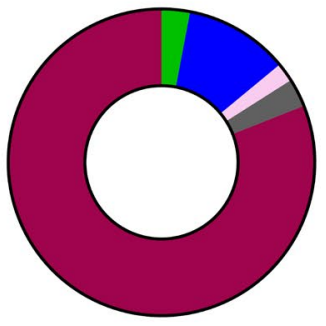

- Green Algae 3\%

- Diatoms $11 \%$

Euglenophytes 2\%

- Cryptophytes 3\%

- Cyanobacteria $81 \%$

\section{Nearshore waters in the late-stratified season}

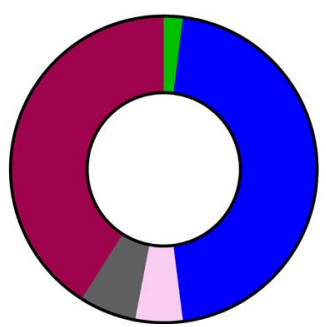

Cryptophytes $6 \%$

- Cyanobacteria $41 \%$
Offshore waters in the mixed season

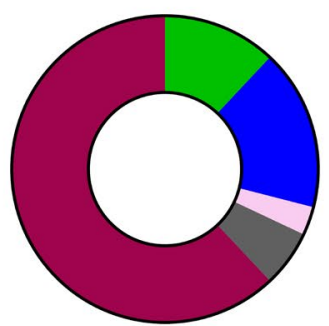

- Green Algae 12\%

- Diatoms $17 \%$

Euglenophytes 3\%

- Cryptophytes 6\%

- Cyanobacteria $62 \%$
Offshore waters in the early-stratified season

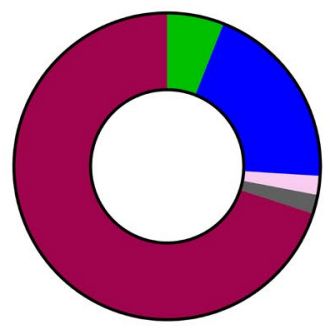

- Green Algae 6\%

- Diatoms 20\%

- Euglenophytes 2\%

- Cryptophytes $2 \%$

- Cyanobacteria $70 \%$

\section{Offshore waters in the late-stratified season}

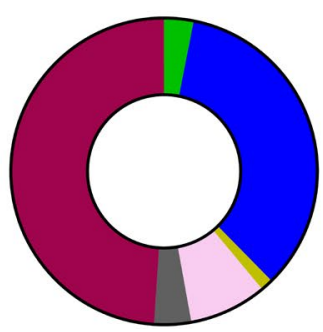

- Green Algae 3\%

- Diatoms 35\%

- Dinoflagellates 1\%

- Euglenophytes 8\%

- Cryptophytes $4 \%$

- Cyanobacteria $49 \%$

FIGURE 6 Seasonal (mixed vs. early-stratified vs. late-stratified periods) and spatial (nearshore vs. offshore waters) variations in the euphotic layer of the relative contribution (\%) of phytoplankton taxa to chlorophyll-a

cyanobacteria with heterocysts (Hecky, 1993). By comparison with the historical accounts (Hecky, 1993; Kling et al., 2001; Talling, 1987), the phytoplankton of Lake Victoria still appears dominated by diatoms and cyanobacteria (Figure 6), with, however, a few important changes in the composition at species level. In contrast to the 1990 s where cyanobacteria were dominated by heterocystous and gas-vacuolated taxa, the present assemblage appears dominated by coccal/colonial and non-heterocystous filamentous cyanobacteria (predominance of coccal [67 taxa] and filamentous [20] species over heterocystous taxa [12]).

\section{4 | DISCUSSION}

\section{1 | Climatic controls on Lake Victoria stratification, oxygenation, and chlorophyll- $a$}

In contrast to Talling's observations in the 1960s, Hecky (1993) found the lake warmer and more stably stratified for much of the year and this caused an increase of anoxia in bottom waters. The warmer and more stably stratified lake in the 1990s than in the 1960 s was in agreement with the positive air temperature trend over Lake Victoria since the early 1980 s, a trend also observed by Hulme et al. (2001). Further, there is also some evidence that the present lake is warmer than in the 1990 s and early 2000 s. Considering that our measurements carried out in June, October, and March 20182019 are representative of the three stratification phases observed by Talling (1966), the yearly-integrated surface waters temperature was $25.7 \pm 0.7^{\circ} \mathrm{C}(n=19,925)$ in $2018-2019$. This value is significantly ( $p<0.0001$, Mann-Whitney test) higher than temperatures of surface waters measured during lake-wide surveys in the early 2000s, notably during the Lake Victoria Environmental Project (LVEMP) and Lake Victoria Fisheries Research Project (LVRFP) surveys. In addition, Talling (1966) observed hypolimnetic water temperatures as low as $23.5^{\circ} \mathrm{C}$ in the $1960 \mathrm{~s}$, close to the $23.8^{\circ} \mathrm{C}$ reported by Hecky et al., (1994) in the 1990s, whereas we did not observe hypolimnetic temperatures lower than $24.2^{\circ} \mathrm{C}$. Our observations agree with those of Sitoki et al. (2010) and Marshall et al. (2013) who both showed that the thermal gradients have decreased over time in Lake Victoria. In 2006-2009, Sitoki et al. (2010) also showed that bottom waters in the late-stratified season (February-March) were oxygenated. Subsequently, Sitoki et al. (2010) stipulated this has caused a less intense stratification and thus has reduced anoxia in bottom waters in the 2000 s comparing to the situation observed in the 1990s. In contrast to the situation observed by Sitoki et al. (2010), we concomitantly observed anoxia in bottom waters in all offshore 


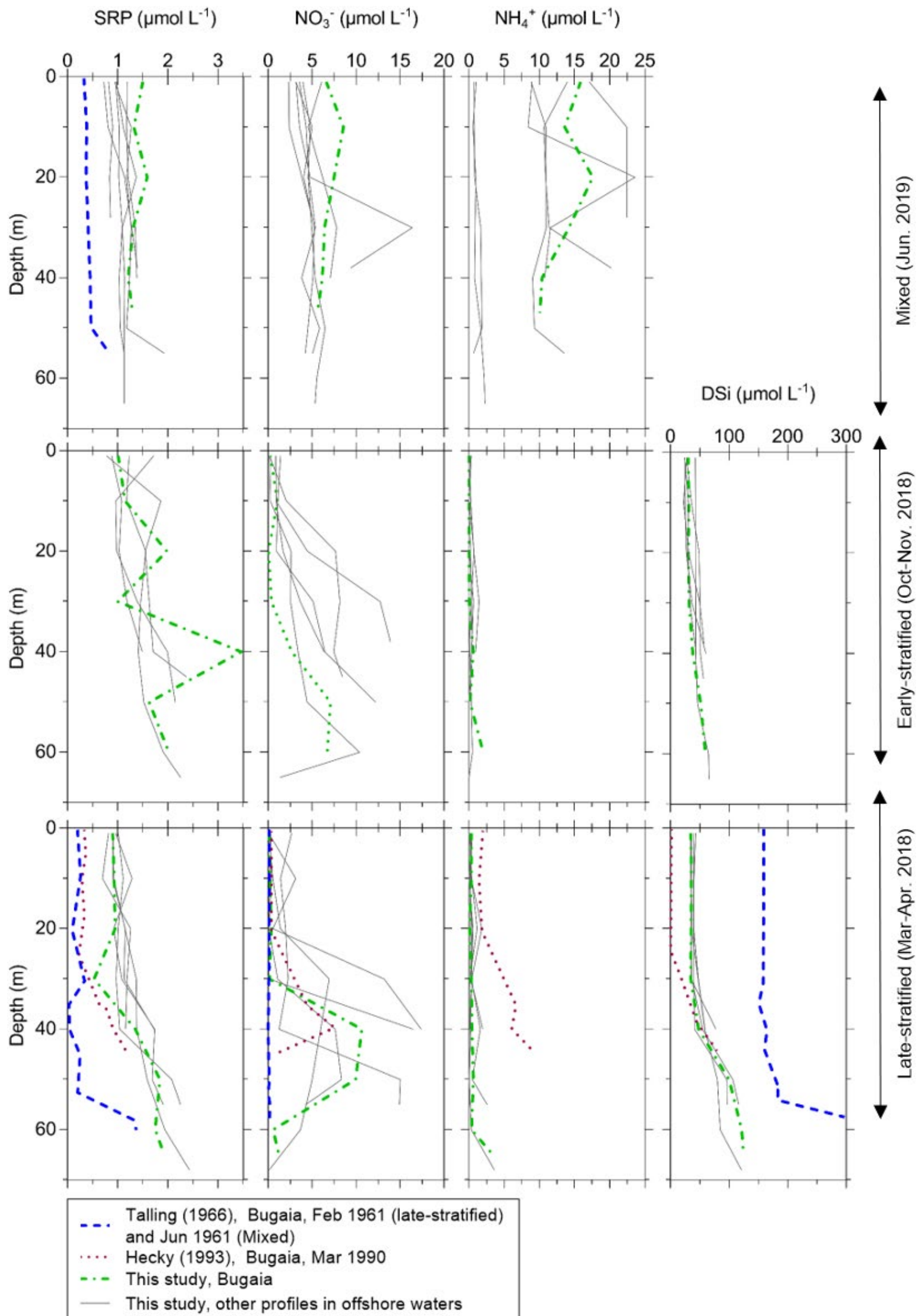

FIGURE 7 Vertical profiles during the different seasons (mixed vs. early-stratified vs. late-stratified periods) showing SRP ( $\mu$ mol/L), $\mathrm{NH}_{4}^{+}(\mathrm{mg} / \mathrm{L}), \mathrm{Si}(\mu \mathrm{mol} / \mathrm{L})$ and $\mathrm{NO}_{3}^{-}$concentrations ( $\left.\mu \mathrm{mol} / \mathrm{L}\right)$. For matters of comparison with historical data, Talling's historical station (UP2; Figure 1) is highlighted in colour. Additional information on historical data is available in Table S4 
stations and a lower thermal gradient within the water column during the late-stratified period in 2018-2019. This suggests that the thermal gradient within the water column is probably not the main factor controlling anoxia in offshore waters. In addition, we did not observe anoxia in bottom waters during the early-stratified season of 2018-2019, in contrast to 1990-1991 during the same period of the year. After the annual lake mixing in June-August, this probably indicated that deoxygenation of the deeper waters appears presently later in the year than in the 1990s, a situation also observed during lake-wide surveys by Mwirigi et al. (2005) in October 2000. In the absence of a regular long-term monitoring of meteorological, physical, and ecological parameters in Lake Victoria, it is difficult to understand with certainty the cause of this phenomenon. Since the early 2000s, lower and/or delayed anoxia were concomitant with an increasing trend of wind speed over the lake. Therefore, we assume that wind speed over Lake Victoria emerges as an important control factor on oxygen dynamics in the lake, as wind speed can indeed accelerate ventilation and mixing.

The between-year differences in seasonal stratification indicate that, despite general air temperature increase in the Victoria region, the controls on mixing dynamics are more complex because of interannual changes in wind speed (Maclntyre, 2013). The betweenyear differences result from variations in the surface meteorology over Lake Victoria as it responds to decadal-scale variations in Indian Ocean temperature coupled with inter-annual variations in phase of El Niño and the Indian Ocean Dipole (Maclntyre, 2013). Indeed, the sampled period in the 1990s corresponded to phase of a marked El Niño conditions (negative SOI) that might have contributed to lower wind speed conditions, as indicated by significant positive correlation between wind speed over the lake and SOI. According to Maclntyre (2013), this probably causes Lake Victoria to shift between states in which anoxic volume is extensive during low wind years (as in the early 1990s) and states in which anoxia volume is less extensive during stronger wind years (as since the early 2000s). The years with stronger winds enabling the heat in surface waters to be transferred deeper during vertical mixing (Paugy \& Levêque, 2019), favouring the establishment of a deeper thermocline as in 2018-2019. The opposite is also true, with the establishment of a shallower thermocline during low wind years as in the 1990s. The ECMWF ERA5 wind data confirm indeed that a low wind speed period with prevailing El Niño conditions occurred during the 1990-1997 period and since then a general increasing trend is observed. The deeper thermocline results in increasing the mixed layer, which eventually lowers the lake productivity in comparison to the 1990s during stratified periods. Deep mixing could limit production by causing phytoplankton to spend a large fraction of the time at insufficient/low light (Murphy, 1962), producing a condition of light limitation in Lake Victoria (Lehman et al., 1998). In contrast, the thermocline in the 1990s was shallower enabling of the lake phytoplankton to stay suspended in the upper well illuminated layer, allowing greater productivity.

Further, cross-lake surveys in Lake Victoria indicated that reduction of the anoxic volume during period of deeper thermocline in some years would eventually result in reduction of phosphorus loading and in greater mixing, lowering productivity (Kolding et al., 2008). This could be an explanation for the much lower phytoplankton biomass observed in this study in comparison with the 1990s. The much lower phytoplankton biomass in the surface waters could also have affected the oxygen content in the deeper waters. Indeed, if less phytoplankton organic matter settles to sediment, the oxygen demand would be lower, thereby lowering/delaying deoxygenation of the deeper waters. In the 1990s, oversaturation by oxygen in surface waters was caused by the intense warming during daylight that created a diurnal stratification that kept the algae suspended near the surface allowing high rates of photosynthesis (Hecky, 1993). According to the increasing trend of air temperature over the lake, we would expect presently a greater diurnal stratification in the offshore waters and thus higher oxygen saturation of surface waters. In 2018-2019, the oxygen saturation level in surface waters was lower than that observed in the 1990s, approaching oxygen saturation levels observed in the 1960 s by Talling (1966). Indeed, the majority of the vertical profiles in water temperature did not exhibit strong diurnal stratification, suggesting that air temperature was not the only factor controlling this phenomenon, as air humidity, evaporation, and wind stress should be important, and conditions became more windier in 2018-2019.

\subsection{Historical changes in phytoplankton composition in relation with stratification}

A substantial change from the pattern described by Talling (1987) is that cyanobacteria now benefit from more or less intense mixing, as they developed better in mixed and early-stratified conditions, whereas the diatoms developed better in late-stratified conditions. This may seem counter-intuitive, as many cyanobacteria taxa are known to thrive in stratified conditions and to be associated with higher particulate $\mathrm{C}: \mathrm{N}$ ratio (usually found during stratified conditions due to denitrification losses below the thermocline), theoretically favouring efficient $\mathrm{N}_{2}$-fixers. Many of the coccal taxa may actually benefit from vertical turbulence and from physical variability of the water column at short time scales that may operate in Lake Victoria. Indeed, it was shown that mixing of the water column in Pilkington Bay may occur on a daily basis (Maclntyre et al., 2002), possibly allowing greater availability of dissolved $\mathrm{N}$ and $\mathrm{P}$ for non $\mathrm{N}_{2}$-fixing cyanobacteria.

As for diatoms, the most abundant taxa were thin-walled, needle-shaped Nitzschia spp. which, thanks to their high surface to volume ratio are better adapted to stratification and able to cope with a moderate nutrient depletion (Kilham et al., 1986; Reynolds, 2006). The DSi concentrations throughout the water column shows a clear historical trend, decreasing from the 1960s to the 1990s and increasing from the 1990s to present, the latter agreeing with the present reappearance of Aulacoseira spp. During the 1960s to 1990s, the DSi stock was reduced as a result of increased diatom activity (Verschuren et al., 2002) to a level 
where diatom growth and abundance was limited. Notably, Stager et al. (2009) concluded that the past Aulacoseira/Nitzschia transition might have occurred because of a change in mixing conditions towards greater stratification, resulting from reduced wind speed and atmospheric warming, in addition to changes in nutrient inputs from intensified land use. It implies that extended period of greater stratification between the 1960s and 1990s has eventually reduced diatom productivity because of the reduction of internal DSi loading from deeper waters. The corollary is that the reappearance of Aulacoseira could be originating from an increase in wind speed over the lake that allows the establishment of more mixed conditions throughout the year, preventing DSi to be trapped in the hypolimnetic waters. Lehman et al. (1998) showed that under climatic conditions that promote deep mixing (as in 2018-2019) dissolved nutrients are not limiting and competition among algae is based on photosynthetic efficiency at low average light, favouring diatom production. DSi arise mainly from soil weathering and thus can be provided only via riverine inputs, and, given the long water residence time, a long period would be required to replenish this DSi deficit. In comparison to the 1990s, DSi concentrations in surface waters increased significantly $(p<0.001$, Mann-Whitney test). This suggests that DSi concentrations could increase again in the future if windy conditions continue, with a new rising potential for diatoms productivity.

\section{3 | Light, nutrient, and grazing controls on chlorophyll-a}

Chlorophyll- $a$ concentrations have significantly decreased over time and therefore we expected a positive impact on lake water transparency since algal biomass was the main factor controlling lake water transparency in the 1990s (Mugidde, 1993; Silsbe et al., 2006). Accordingly, SD and $Z_{\text {eu }}$ were significantly $(p<0.001$, Mann-Whitney) higher in the offshore waters in 2018-2019 than in the 1990s whereas the light attenuation decreased significantly ( $p<0.001$, Mann-Whitney). However, the high $I_{k}: I_{z m}$ ratio suggests that phytoplankton growth is presently limited by light as in the 1990s. In addition, the high non-phytoplankton carbon fraction in the POC suggests that self-shading in the lake is now less intense than in the 1990s and that detrital/microbial carbon as well as total suspended matter play a larger role in determining the water transparency of the lake in 2018-2019. Lake Victoria is shallow for such a large lake and so it is likely that the increasing trend of wind speed over Lake Victoria since the late 1990 s led to higher resuspension of detrital particles from lake sediment.

Given that a large fraction of the POC is actually detrital/microbial, interpretation of the seston elemental ratios is uncertain. Notably, the dominance of Lake Victoria phytoplankton by coccal/colonial forms and non-heterocystous filamentous taxa in our samples may be fully compatible with moderate $\mathrm{N}$-limitation. Indeed, according to several physiological studies (e.g. Bergman et al., 1997), $\mathrm{N}_{2}$-fixation is not limited to heterocystous cyanobacteria. Another finding that support our conclusion that the present lake is moderately limited by $\mathrm{N}$ is the increase of primary production when the lake mixes and when inorganic $\mathrm{N}$ become more available. Denitrification rates are likely to be a persistent feature of Lake Victoria even without anoxic conditions because of the high organic content of pelagic sediments. Therefore, whether the $\mathrm{N}$ content of lake rises or falls is probably most dependent on $\mathrm{N}$ fixation rates. Thus, the significant ( $p<0.001$; Mann-Whitney test) lower PN concentrations in 2018-2019 compared to the 1990s may indicate that $\mathrm{N}_{2}$-fixation has significantly decreased, possibly related to the change in the phytoplankton composition. In addition, we would expect less inorganic $\mathrm{N}$ in the deep water if $\mathrm{N}_{2}$-fixation in the lake has decreased, as suggested by the vertical profile of $\mathrm{NH}_{4}^{+}$during the late-stratified period of 1990 and 2018-2019.

Further, according to the N:P particulate ratio, primary production does not seem limited by $P$ in 2018-2019, as in the 1990s (Hecky, 1993). Besides, at Talling's historical station, SRP was overall higher throughout the water column in 2018-2019 than in the 1990s. In comparison to Mugidde (1992), we observed presently similar ( $p>0.05$, Mann-Whitney) or slightly ( $p>0.05$, Mann-Whitney) lower SRP concentration, in nearshore and offshore waters, respectively. Altogether, this indicates that the present lake is still submitted to a strong pressure by inorganic nutrients, especially $\mathrm{P}$, which is unlikely to explain the historical decrease of chlorophyll-a.

Given that present nutrient concentrations have not decreased compared to 1990 s we can envisage a possible top-down explanation to explain the historical decrease in chlorophyll-a. Palaeolimnological studies have shown that the lake started its transition towards eutrophication before the introduction of the Nile Perch in the 1980s (Hecky et al., 2010; Stager et al., 2009). This conclusion precludes the possibility that management of the fishery through increased fishing mortality on Nile perch alone can lead to reversal of the changes in water quality or recovery of the multitude of species that formerly occupied the lake (Balirwa et al., 2003; Hecky et al., 2010). Historical zooplankton data are lacking but previous grazer manipulations in Lake Victoria by Lehman and Branstrator (1993) demonstrated that chlorophyll- $a$ did not respond significantly to concentration or removal of grazers. In Lake Victoria, the Nile tilapia is the sole fish species that can feed directly on phytoplankton, but it has been observed that Nile tilapia recently changed their diet and are now prey upon large invertebrates and even fish (Njiru et al., 2004). Consequently, we assume that a top-down control could not have reduced (or should have a minimal effect on) chlorophyll- $a$ concentrations in the lake since the 1990s.

\section{5 | CONCLUSIONS}

We showed that chlorophyll-a concentrations in 2018-2019 have substantially decreased compared to 1990s, being closer to levels observed in the 1960s. Maclntyre (2013) highlighted that eutrophication observed by Hecky et al. in the 1990s may have been a consequence of a shift in the regional climate in the 1970s, which resulted from a combined effect of an increase in air temperature and reduced wind speed over the lake, enabling greater stratification of the 
water column. At that time, strong thermal stratification with subsequent hypolimnion anoxia favoured phosphorus mobilisation from the enriched sediments back into the water column. Concomitantly, it also led to denitrification in the hypolimnion creating $\mathrm{N}$-limitation in surface waters, favouring a development of heterocystous cyanobacteria.

We showed an increase of wind speed over the lake since the late 1990s that coincided with a shift from prevailing El Niño to prevailing El Niña conditions. This regional change of climatic conditions strongly imposed light limitation of primary production by deeper mixing compared to the 1990s. Indeed, our observations in 2018-2019 showed that the thermocline was established deeper than in the 1990s and that anoxia in bottom waters was less extensive; we also observed a delay in the appearance of anoxia in bottom waters after the annual lake mixing. This change in vertical mixing, together with an increase in water transparency due to lower algal biomass, might have affected the phytoplankton assemblage, namely, toward lower development of heterocystous cyanobacteria. From our study design, it was not possible to investigate whether this shift in the phytoplankton assemblage could have impacted the historical decrease of chlorophyll-a.

Understanding the interaction between regional climate change and phytoplankton primary production and biomass (chlorophyll-a) is critical for managing and restoring the lake. A possible less windy period in the future resulting from new El Niño phase or from climate change, will probably lead to another episode of eutrophication in Lake Victoria (i.e. high chlorophyll- $a$ in surface waters and anoxia in hypolimnetic waters). As the lake was still saturated by nutrients in 2018-2019, there is need to reduce the nutrient concentrations especially $\mathrm{P}$ to prevent future destructive eutrophic periods caused by reduced mixing.

\section{ACKNOWLEDGMENTS}

This work was funded by the Fonds National de la Recherche Scientifique (FNRS; Lavigas project, contract T.0156.18). The Académie Royale de Belgique (Fonds Agathon de Potter), the Fonds Léopold III and the University of Liège provided additional funding. We thank Marc-Vincent Commarieu for help during sampling, Zita Kelemen (KU Leuven) for her contribution to the stable isotope analyses, Eugen Rott (University of Innsbruck, Austria) for checking identification of some diatoms, and the crew of the MV Hammerkop for their helpful assistance during the cruises. Two anonymous reviewers' suggestions and comments helped greatly improve the manuscript. A.V.B. is a Research Director at the FNRS.

\section{CONFLICT OF INTEREST}

The authors declare they have no conflict of interest.

\section{DATA AVAILABILITY STATEMENT}

Our dataset is publicly available (https://doi.org/10.5281/zenodo. 4247351).

\section{ORCID}

Loris Deirmendjian (iD https://orcid.org/0000-0002-5720-9951

Jean-Pierre Descy (iD https://orcid.org/0000-0003-1649-7800

Cedric Morana iD https://orcid.org/0000-0002-5521-0414

William Okello (iD https://orcid.org/0000-0001-7275-0423

Maya P. Stoyneva-Gärtner (DD https://orcid.org/0000-0003-2439-3737

Steven Bouillon (iD https://orcid.org/0000-0001-7669-2929

Alberto V. Borges iD https://orcid.org/0000-0002-5434-2247

\section{REFERENCES}

Akurut, M. (2017). Water quality analysis and modelling of Inner Murchison Bay, Lake Victoria. PhD Thesis, University of Leuven.

Akurut, M., Niwagaba, C. B., \& Willems, P. (2017). Long-term variations of water quality in the Inner Murchison, Lake Victoria. Environmental Monitoring and Assessment, 189, 22. https://doi.org/10.1007/s1066 1-016-5730-4

Anyah, R. O., Semazzi, F. H. M., \& Xie, L. (2006). Simulated physical mechanisms associated with climate variability over Lake Victoria basin in East Africa. Monthly Weather Review, 134, 3588-3609. https://doi. org/10.1175/MWR3266.1

APHA (1998). Standard methods for examination of water and wastewater, 20th ed. Washington: American Public Health Association, American Water Works Association and Water Environmental Federation.

Balirwa, J. S. (1995). The Lake Victoria environment: Its fisheries and wetlands - A review. Wetlands Ecology and Management, 3, 209-224. https://doi.org/10.1007/BF00179837

Balirwa, J. S., Chapman, C. A., Chapman, L. J., Cowx, I. G., Geheb, K., Kaufman, L., ... Witte, F. (2003). Biodiversity and fishery sustainability in the Lake Victoria basin: An unexpected marriage? BioScience, 53, 703-715. https://doi.org/10.1641/00063568(2003)053[0703:BAFSIT]2.0.CO;2

Bergman, B., Gallon, J. R., Rai, A. N., \& Stal, L. J. (1997). N2 fixation by non-heterocystous cyanobacteria. FEMS Microbiology Reviews, 19, 139-185. https://doi.org/10.1016/S0168-6445(96)00028-9

Bootsma, H. A., Hecky, R. E., \& Ave, E. G. (2003). A comparative introduction to the biology and limnology of the African Great Lakes. Journal of Great Lakes Research, 29, 3-18. https://doi.org/10.1016/ S0380-1330(03)70535-8

Deirmendjian, L., Descy, J.-P., Morana, C., Stoyneva-Gärtner, M., Bouillon, S., Okello, W., \& Borges, A. V. (2020). Dataset for "Ecological changes in Lake Victoria between the late-2010s and the early-1990s". Zenodo, https://doi.org/10.5281/zenodo.4247352

Deirmendjian, L., Lambert, T., Morana, C., Bouillon, S., Descy, J.-P., Okello, W., \& Borges, A. V. (2020). Dissolved organic matter composition and reactivity in Lake Victoria, the world's largest tropical lake. Biogeochemistry, 150, 61-83. https://doi.org/10.1007/s10533020-00687-2

Descy, J.-P., Hardy, M.-A., Stenuite, S., Pirlot, S., Leporcq, B., Kimirei, I., ... Sinyenza, D. (2005). Phytoplankton pigments and community composition in Lake Tanganyika. Freshwater Biology, 50, 668-684. https://doi.org/10.1111/j.1365-2427.2005.01358.x

Fish, G. R. (1955). The food of tilapia in East Africa. Uganda Journal, 19, 85-99.

Fish, G. R. (1956). Chemical factors limiting growth of phytoplankton in Lake Victoria. The East African Agricultural Journal, 21, 152-158. https://doi.org/10.1080/03670074.1956.11665027

Fish, G. R. (1957). A seiche movement and its effect on the hydrology of Lake Victoria. Fish Publication, London, 10, 1-68.

Gikuma-Njuru, P., Rutagemwa, D., Mugidde, R., Hecky, R., MwebazaNdawula, L., Mwirigi, P., ... Kinobe, J. (2005). Eutrophication of the Lake Victoria ecosystem. In F. L. Mwanuzi, J. O. Z. Abuodha, F. J. Muyodi, \& E. R. Hecky (Eds.), Lake Victoria regional water 
quality synthesis report (pp. 81-102). Lake Victoria Environmental Management Project.

Gillikin, D. P., \& Bouillon, S. (2007). Determination of 8180 of water and $\delta 13 \mathrm{C}$ of dissolved inorganic carbon using a simple modification of an elemental analyser-isotope ratio mass spectrometer: An evaluation. Rapid Communications in Mass Spectrometry: An International Journal Devoted to the Rapid Dissemination of Up-to-the-Minute Research in Mass Spectrometry, 21, 1475-1478.

Grahamm, M. (1929). The Victoria Nyanza and its Fisheries: A Report on the Fishing Survey of Lake Victoria, 1927-1928, and Appendices. Crown Agents for the Colonies.

Guildford, S. J., Hecky, R. E., Taylor, W. D., Mugidde, R., \& Bootsma, H. A. (2003). Nutrient enrichment experiments in tropical great lakes Malawi/Nyasa and Victoria. Journal of Great Lakes Research, 29, 89106. https://doi.org/10.1016/S0380-1330(03)70541-3

Guiry, M. D., \& Guiry, G. M. (2019). AlgaeBase. World-wide electronic publication. National University of Ireland, Galway. http://www. algaebase.org/

Hama, T., Miyazaki, T., Ogawa, Y., Iwakuma, T., Takahashi, M., Otsuki, A., \& Ichimura, S. (1983). Measurement of photosynthetic production of a marine phytoplankton population using a stable $13 \mathrm{C}$ isotope. Marine Biology, 73, 31-36. https://doi.org/10.1007/BF00396282

Hecky, R. E. (1993). The eutrophication of Lake Victoria. Internationale Vereinigung Für Theoretische Und Angewandte Limnologie: Verhandlungen, 25, 39-48. https://doi.org/10.1080/03680770.1992.11900057

Hecky, R. E., Bugenyi, F. W. B., Ochumba, P., Talling, J. F., Mugidde, R., Gophen, M., \& Kaufman, L. (1994). Deoxygenation of the deep water of Lake Victoria, East Africa. Limnology and Oceanography, 39, 14761481. https://doi.org/10.4319/lo.1994.39.6.1476

Hecky, R. E., Mugidde, R., Ramlal, P. S., Talbot, M. R., \& Kling, G. W. (2010). Multiple stressors cause rapid ecosystem change in Lake Victoria. Freshwater Biology, 55, 19-42. https://doi. org/10.1111/j.1365-2427.2009.02374.x

Hersbach, H., Bell, B., Berrisford, P., Hirahara, S., Horányi, A., MuñozSabater, J., ... Thépaut, J.-N. (2020). The ERA5 global reanalysis. Quarterly Journal of the Royal Meteorological Society, 146, 1999-2049. https://doi.org/10.1002/qj.3803

Hulme, M., Doherty, R., Ngara, T., New, M., \& Lister, D. (2001). African climate change: 1900-2100. Climate Research, 17, 145-168. https:// doi.org/10.3354/cr017145

Johnson, T. C., Kelts, K., \& Odada, E. (2009). The Holocene history of Lake Victoria. AMBIO: A Journal of the Human Environment, 29, 2-11. https://doi.org/10.1579/0044-7447-29.1.2

Kilham, P., Kilham, S. S., \& Hecky, R. E. (1986). Hypothesized resource relationships among African planktonic diatoms. Limnology and Oceanography, 31, 1169-1181. https://doi.org/10.4319/ lo.1986.31.6.1169

Kirk, J. T. O. (1994). Light and photosynthesis in aquatic ecosystems, Cambridge. Cambridge University Press.

Kling, H. J., Mugidde, R., \& Hecky, R. E. (2001). Recent changes in the phytoplankton community of Lake Victoria in response to eutrophication. In M. Munawar \& R. Hecky (Eds.), Great Lakes of the World: Food webs, health and integrity (pp. 47-66). Backhuys.

Kociolek, J. P., Blanco, S., Coste, M., Ector, L., Karthick, B., Kulikovskiy, M., ... Witkowski, J. (2020). DiatomBase. http://www.diatombase.org

Kolding, J., Van Zwieten, P., Mkumbo, O., Silsbe, G., \& Hecky, R. (2008). Are the Lake Victoria fisheries threatened by exploitation or eutrophication? Towards an ecosystem-based approach to management. In G. Bianchi \& H. R. Skjoldal (Eds.), The ecosystem approach to fisheries (p. 309). FAO.

Komarek, J., \& Hauer, T. (2020). CyanoDB. cz-On-line database of cyanobacterial genera. Word-wide electronic publication, Univ. of South Bohemia \& Inst. of Botany AS CR.

Krammer, K., \& Lange-Bertalot, H. (1991). Bacillariophyceae 3. Teil Centrales Fragilariaceae, Eunotiaceae. Spektrum.
Krammer, K., \& Lange-Bertalot, H. (1997a). Bacillariophyceae, 1. Teil: Naviculaceae. Gustav Fis.

Krammer, K., \& Lange-Bertalot, H. (1997b). Bacillariophyceae, 2. Teil: Bacillariaceae, Epithemiaceae, Surirellaceae. Spektrum.

Krammer, K., \& Lange-Bertalot, H. (2004). Bacillariophyceae. Teil 4: Achnanthaceae. Kritische Ergänzungen zu Achnanthes sl, Navicula s. str., Gomphonema Gesamtliteraturverzeichnis [second revised edition], Spektrum. In H. Ettl, J. Gerloff, H. Heynig, \& D. Mollenhauer (Hrsg/Eds), Süwasserflora von Mitteleuropa. Spektrum.

Lehman, J. T. (2009). Lake Victoria. In H. J Dumont (Ed.), The Nile (pp. 215-241). Dordrecht: Springer. https://www.springer.com/fr/ book/9781402097256\#otherversion $=9789401777209$.

Lehman, J. T., \& Branstrator, D. K. (1993). Effects of nutrients and grazing on the phytoplankton of Lake Victoria. Internationale Vereinigung Für Theoretische Und Angewandte Limnologie: Verhandlungen, 25, 850855. https://doi.org/10.1080/03680770.1992.11900265

Lehman, J. T., Mugidde, R., Box, P. D., \& Lehman, D. A. (1998). Lake Victoria plankton ecology: Mixing depth and climate driven control of lake condition. In J. T. Lehman (Ed.), Environmental change and response in East African Lakes (pp. 99-116). Dordrecht: Springer.

Lung'Ayia, H. B. O., M'harzi, A., Tackx, M., Gichuki, J., \& Symoens, J. J. (2000). Phytoplankton community structure and environment in the Kenyan waters of Lake Victoria. Freshwater Biology, 43, 529-543. https://doi.org/10.1046/j.1365-2427.2000.00525.x

Maclntyre, S. (2013). Climatic variability, mixing dynamics, and ecological consequences in the African Great Lakes. In C. R Goldman, M. Kumagai \& D. Robarts (Eds.), Climatic change and global warming of inland waters: Impacts and mitigation for ecosystems and societies (pp. 311-336). Wiley.

MacIntyre, S., Romero, J. R., \& Kling, G. W. (2002). Spatial-temporal variability in surface layer deepening and lateral advection in an embayment of Lake Victoria, East Africa. Limnology and Oceanography, 47, 656-671. https://doi.org/10.4319/lo.2002.47.3.0656

Mackey, M. D., Mackey, D. J., Higgins, H. W., \& Wright, S. W. (1996). CHEMTAX - A program for estimating class abundances from chemical markers: Application to HPLC measurements of phytoplankton. Marine Ecology Progress Series, 144, 265-283. https://doi. org $/ 10.3354 /$ meps144265

Marshall, B. E., Ezekiel, C. N., Gichuki, J., Mkumbo, O. C., Sitoki, L., \& Wanda, F. (2013). Has climate change disrupted stratification patterns in Lake Victoria, East Africa? African Journal of Aquatic Science, 38, 249-253. https://doi.org/10.2989/16085914.2013.810140

Mugidde, R. (1992). Changes in phytoplankton productivity and biomass in Lake Victoria (Uganda). PhD Thesis, University of Waterloo.

Mugidde, R. (1993). The increase in phytoplankton primary productivity and biomass in Lake Victoria (Uganda). Internationale Vereinigung Für Theoretische Und Angewandte Limnologie: Verhandlungen, 25, 846849. https://doi.org/10.1080/03680770.1992.11900264

Mugidde, R. (2001). Nutrient status and planktonic nitrogen fixation in Lake Victoria, Africa. PhD Thesis, University of Waterloo.

Mugidde, R., Hecky, R. E., Hendzel, L. L., \& Taylor, W. D. (2003). Pelagic nitrogen fixation in Lake Victoria (East Africa). Journal of Great Lakes Research, 29, 76-88. https://doi.org/10.1016/S0380-1330(03)70540

Murphy, G. I. (1962). Effect of mixing depth and turbidity on the productivity of fresh-water impoundments. Transactions of the American Fisheries Society, 91, 69-76. https://doi.org/10.1577/15488659(1962)91[69:EOMDAT]2.0.CO;2

Murphy, J., \& Riley, J. P. (1962). A modified single solution method for the determination of phosphate in natural waters. Analytica Chimica Acta, 27, 31-36. https://doi.org/10.1016/S0003-2670(00)88444-5

Mwirigi, P., Rutagemwa, D. K., Gikuma-Njuru, P., Matovu, A., Waya, R. K., Mwebaza-Ndawula, L., SsenfumaNsubuga, M., ... Hecky, R. E. (2005). Lake Victoria: The changing lake. In F. L. Mwanuzi, J. O. Z. Abuodha, F. J. Muyodi, \& E. R. Hecky (Eds.), Lake Victoria regional water 
quality synthesis report (pp. 62-80). Lake Victoria Environmental Management Project.

Nicholson, S. E. (1996). A review of climate dynamics and climate variability in Eastern Africa. In Johnson (Ed.), Limnology, climatology and paleoclimatology of the East African Lakes (pp. 24-56). Gordon and Breach.

Nicholson, S. E. (2018). The ITCZ and the seasonal cycle over equatorial Africa. Bulletin of the American Meteorological Society, 99, 337-348. https://doi.org/10.1175/BAMS-D-16-0287.1

Njiru, M., Okeyo-Owuor, J. B., Muchiri, M., \& Cowx, I. G. (2004). Shifts in the food of Nile tilapia, Oreochromis niloticus (L.) in Lake Victoria, Kenya. African Journal of Ecology, 42, 163-170.

Paugy, D., \& Levêque, C. (2019). Le lac Victoria: Un écosystème bouleversé par l'Homme. IRD Éditions.

Reynolds, C. S. (2006). The ecology of phytoplankton (Ecology, Biodiversity and Conservation). Cambridge University Press, Cambridge, UK.

Riley, G. A. (1957). Phytoplankton of the North Central Sargasso Sea, 1950-52 1. Limnology and Oceanography, 2, 252-270. https://doi. org/10.1002/Ino.1957.2.3.0252

Sarmento, H., Isumbisho, M., \& Descy, J. P. (2006). Phytoplankton ecology of Lake Kivu (eastern Africa). Journal of Plankton Research, 28, 815-829. https://doi.org/10.1093/plankt/fbl017

Schneider, D. P., Deser, C., Fasullo, J., \& Trenberth, K. E. (2013). Climate data guide spurs discovery and understanding. Eos, Transactions American Geophysical Union, 94, 121-122. https://doi. org/10.1002/2013EO130001

Silsbe, G. M., Hecky, R. E., Guildford, S. J., \& Mugidde, R. (2006). Variability of chlorophyll a and photosynthetic parameters in a nutrient-saturated Tropical Great Lake. Limnology and Oceanography, 51, 2052-2063. https://doi.org/10.4319/lo.2006.51.5.2052

Sitoki, L., Gichuki, J., Ezekiel, C., Wanda, F., Mkumbo, O. C., \& Marshall, B. E. (2010). The environment of Lake Victoria (East Africa): Current status and historical changes. International Review of Hydrobiology, 95, 209-223. https://doi.org/10.1002/iroh.201011226

Sitoki, L., Kofler, W., \& Rott, E. (2013). Planktonic needle-shaped Nitzschia species from Lake Victoria, Africa, revisited. Diatom Research, 28, 165-174.

Ssebuggwawo, V., Kitamirike, J. M., Khisa, P., Njuguna, H., Myanza, O., Hecky, R. E., \& Mwanuzi, F. L. (2005). Hydraulic/hydrodynamic conditions of Lake Victoria. In F. L. Mwanuzi, J. O. Z. Abuodha, F. J. Muyodi, \& E. R. Hecky (Eds.), Lake Victoria regional water quality synthesis report (pp. 42-61). Lake Victoria Environmental Management Project.

Stager, J. C., Hecky, R. E., Grzesik, D., Cumming, B. F., \& Kling, H. (2009a). Diatom evidence for the timing and causes of eutrophication in Lake Victoria, East Africa. Hydrobiologia, 636, 463-478. https://doi. org/10.1007/s10750-009-9974-7

Stoyneva-Gärtner, M. P., Morana, C., Borges, A. V., Okello, W., Bouillon, S., Deirmendjian, L., ... Descy, J.-P. (2020). Diversity and ecology of phytoplankton in Lake Edward (East Africa): Present status and longterm changes. Journal of Great Lakes Research, 46, 741-751. https:// doi.org/10.1016/j.jglr.2020.01.003

Talling, J. F. (1957a). Diurnal changes of stratification and photosynthesis in some tropical African waters. Proceedings of the Royal Society of London. Series B - Biological Sciences, 147, 57-83. https://doi. org/10.1098/rspb.1957.0036

Talling, J. F. (1957b). Some observations on the stratification of Lake Victoria. Limnology and Oceanography, 2, 213-221. https://doi. org/10.1002/Ino.1957.2.3.0213
Talling, J. F. (1965). The photosynthetic activity of phytoplankton in East African lakes. Internationale Revue Der Gesamten Hydrobiologie Und Hydrographie, 50, 1-32. https://doi.org/10.1002/iroh.19650 500102

Talling, J. F. (1966). The annual cycle of stratification and phytoplankton growth in Lake Victoria (East Africa). Internationale Revue Der Gesamten Hydrobiologie Und Hydrographie, 50, 1-32. https://doi. org/10.1002/iroh.19660510402

Talling, J. F. (1987). The phytoplankton of Lake Victoria (East Africa). Archiv Fur Hydrobiologie, 25, 229-256.

Talling, J. F., \& Talling, I. B. (1965). The chemical composition of African Lake Waters. Internationale Revue Der Gesamten Hydrobiologie Und Hydrographie, 60, 421-463. https://doi.org/10.1002/iroh.19650 500307

United Nations Environment Programme (UNEP) (2008). Africa's Lakes: Atlas of our changing environment. Division of Early Warning and Assessment (DEWA).

Valderrama, J. C. (1981). The simultaneous analysis of total nitrogen and total phosphorus in natural waters. Marine Chemistry, 10, 109-122. https://doi.org/10.1016/0304-4203(81)90027-X

Vanderkelen, I., van Lipzig, N. P. M., \& Thiery, W. (2018). Modelling the water balance of Lake Victoria (East Africa) - Part 1: Observational analysis. Hydrology and Earth System Sciences, 22, 5509-5525.

Verschuren, D., Johnson, T. C., Kling, H. J., Edgington, D. N., Leavitt, P. R., Brown, E. T., ... Hecky, R. E. (2002). History and timing of human impact on Lake Victoria, East Africa. Proceedings of the Royal Society B: Biological Sciences, 269, 289-294. https://doi.org/10.1098/ rspb.2001.1850

Vollenweider, R. A. (1965). Calculation models of photosynthesis-depth curves and some implications regarding day rate estimates in primary production measurements. Memorie Dell'istituto Italiano Di Idrobiologia, 18, 425-457.

Westwood, D. (1981). Ammonia in waters. Methods for the examination of waters and associated materials. London, United Kingdom: HMSO.

Worthington, E. B. (1930). Observations on the Temperature, Hydrogenion concentration, and other physical conditions of the Victoria and Albert Nyanzas. Internationale Revue Der Gesamten Hydrobiologie Und Hydrographie, 24, 328-357. https://doi.org/10.1002/iroh.19300 240306

Wright, S. W., Jeffrey, S. W., Mantoura, R., Llewellyn, C. A., Bjornland, T., Repeta, D., \& Welschmeyer, N. (1991). Improved HPLC method for the analysis of chlorophylls and carotenoids from marine phytoplankton. Marine Ecology Progress Series, 77, 183-196. https://doi. org/10.3354/meps077183

\section{SUPPORTING INFORMATION}

Additional supporting information may be found online in the Supporting Information section.

How to cite this article: Deirmendjian L, Descy J-P, Morana

$C$, et al. Limnological changes in Lake Victoria since the mid-20 ${ }^{\text {th }}$ century. Freshw Biol. 2021;00:1-18. https://doi. org/10.1111/fwb.13780 